\title{
Mono-, di- and tetrarhenium Fischer carbene complexes with thienothiophene substituents
}

\footnotetext{
Zandria Lamprecht, ${ }^{a}$ Shankara Radhakrishnan, ${ }^{a}$ Alexander Hildebrandt, ${ }^{\mathrm{b}}$ Heinrich Lang, ${ }^{\mathrm{b}}$ David C. Liles, ${ }^{a}$ Nora-ann Weststrate, ${ }^{a}$ Simon Lotz ${ }^{\mathrm{a}}$ and Daniela I. Bezuidenhout, ${ }^{\mathrm{a}, \mathrm{c},{ }^{*}}$

The oxidative cleaving of a rhenium-rhenium bond by bromine in binuclear Fischer carbene complexes proves to be an effective method to prepare mononuclear bromido-carbene complexes. The reaction of mono- and dilithiated thieno[2,3$b]$ thiophene $\left(2,3-b-\mathrm{TTH}_{2}\right)$ and thieno[3,2-b]thiophene $\left(3,2-b-\mathrm{TTH}_{2}\right)$ with $\left[\mathrm{Re}_{2}(\mathrm{CO})_{10}\right]$ afford dirhenium nonacarbonyl ethoxycarbene complexes, $\left[\operatorname{Re}_{2}(C O)_{9}\{C(O E t) 2,3-b-T T H\}\right](1 \mathbf{a})$ and $\left[\operatorname{Re}_{2}(C O){ }_{9}\{C(O E t) 3,2-b-T T H\}\right](1 \mathbf{b})$, and the tetrarhenium bis $\left\{\right.$ ethoxycarbene) complexes from the dilithiated thiophene substrates, $\left[\left\{\operatorname{Re}_{2}(\mathrm{CO})_{9} \mathrm{C}(\mathrm{OEt})\right\}_{2}\{\mu-2,3-b-\mathrm{TT}\}_{2}\right] \quad(2 \mathrm{a})$ and $\left[\left\{\operatorname{Re}_{2}(\mathrm{CO}){ }_{9} \mathrm{C}(\mathrm{OEt})\right\}_{2}\{\mu-3,2-b\right.$-TT $\left.\}\right](\mathbf{2 b})$ featuring bridging thiophene linkers. Rhenium-rhenium bond cleavage by bromine of the monocarbene complexes yielded the scarce class of monorhenium bromido-carbene complexes, cis$\left[\operatorname{Re}(\mathrm{CO})_{4}\{\mathrm{C}(\mathrm{OEt}) 2,3-b-\mathrm{TTH}\} \mathrm{Br}\right](3 \mathrm{a})$ and $c i s-\left[\operatorname{Re}(\mathrm{CO})_{4}\{\mathrm{C}(\mathrm{OEt}) 3,2-b-\mathrm{TTH}\} \mathrm{Br}\right](3 \mathrm{~b})$, while the corresponding reaction of the biscarbene tetrarhenium carbonyl complex of thieno[2,3-b]thiophene afforded the cleaving of both metal-metal bonds to give the novel dirhenium biscarbene dibromido complex with a thienothiophene spacer, $\left[\left\{\operatorname{Re}(\mathrm{CO})_{4} \mathrm{Br}(\mathrm{C}(\mathrm{OEt})\}_{2}\{\mu-2,3-b-\mathrm{TT}\}\right]\right.$ (4a). A new indirect aminolysis route is described to prepare the chlorido dimethylaminocarbene complex $\mathbf{5 a}$ cis$\left[\operatorname{Re}(\mathrm{CO})_{4}\left\{\mathrm{C}\left(\mathrm{NMe}_{2}\right) 2,3-b-\mathrm{TTH}\right\} \mathrm{Cl}\right]$, with unexpected cleavage of the Re-Re bond. Single crystal X-ray diffraction studies were performed on $\mathbf{1 a}, \mathbf{2 a}, \mathbf{3 a}, \mathbf{5 a}, \mathbf{1} \mathbf{b}$ and $\mathbf{3 b}$. Spectroscopic and electrochemical methods are employed to investigate the electronic effect of the different conjugation pathways in the different thienothiophenyl carbene substituents, and the replacement of the rhenium pentacarbonyl fragment with a bromido ligand.
}

\section{Introduction}

The syntheses and applications of neutral rhenium carbonyl complexes of the type, $\left[\operatorname{Re}(\mathrm{CO})_{4}(\right.$ carbene $\left.) \mathrm{X}\right]$, containing both a Fischer alkoxycarbene and halogen ligand, are under-explored, ${ }^{1}$ in contrast to the more prevalent dirhenium nonacarbonyl Fischer carbene complex (FCC) analogues. ${ }^{2}$ This can be ascribed to the challenging synthetic procedure that result as a consequence of the competitive nature of the nucleophilic attack on carbonyl ligands and lithium-halogen exchange reactions with $\left[\mathrm{M}(\mathrm{CO})_{5} \mathrm{X}\right](\mathrm{M}=\mathrm{Mn}$, $\operatorname{Re} ; \mathrm{X}=\mathrm{Br}, \mathrm{I})$.

\footnotetext{
a. Department of Chemistry, University of Pretoria, Private Bag X20, Hatfield 0028,

Pretoria, South Africa.

${ }^{b .}$ Technische Universität Chemnitz, Fakultät für Naturwissenschaften, Institut für Chemie, Anorganische Chemie, D-09107 Chemnitz, Germany.

c. Molecular Sciences Institute, School of Chemistry, University of the

Witwatersrand, Johannesburg 2050, South Africa.

† Footnotes relating to the title and/or authors should appear here.
}

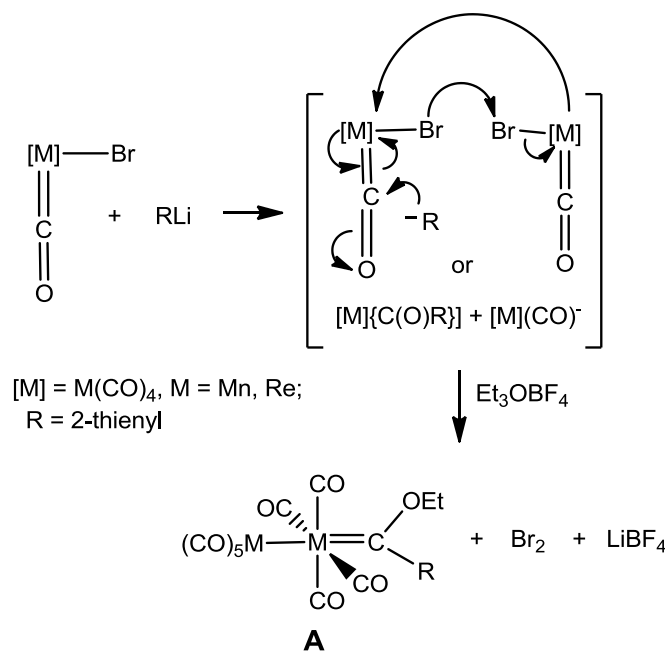

Scheme 1 Metal-metal bond formation with a Fischer carbene ligand (low yield) from the reaction of group 7 transition metal carbonyl halides and thienyllithium. 
(i)

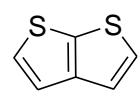

2,3-b- $\mathrm{TTH}_{2}$ (ii)<smiles>c1cc2sccc2s1</smiles>

3,2-b-TTH
Fig. 1 Condensed thiophene substrates for Fischer carbene complex synthesis

Scheme 1 illustrates the fate of two $\operatorname{Re}(\mathrm{CO}){ }_{5} \mathrm{Br}$ precursors being modified during the lithiation process to give monocarbene dirhenium nonacarbonyl complex $\mathbf{A}$ after alkylation, and suggests the elimination of $\mathrm{Br}_{2}{ }^{1 a, 3}$ Alternatively, a radical mechanism could also account for the metal-metal bond formation. In addition, low yields (less than $10 \%$ ) of the resulting dirhenium nonacarbonyl FCCs, are reported. The preferred approach for the synthesis of $\mathbf{A}$ is the direct reaction of thienyllithium (RLi) with $\left[\operatorname{Re}_{2}(\mathrm{CO})_{10}\right]$ which affords $\left[\operatorname{Re}_{2}(\mathrm{CO})_{9}\{\mathrm{C}(\mathrm{OEt}) \mathrm{R}\}\right]$ in almost quantitative yields. ${ }^{1 a, 2 c, d}$ Monometal carbene bromido complexes of rhenium are not accessible by the direct reaction of lithiated thiophene with $\left[\mathrm{Re}(\mathrm{CO})_{5} \mathrm{Br}\right]$. However, unlike for the analogous $\left[\mathrm{Mn}(\mathrm{CO})_{5} \mathrm{Br}\right]$, it is possible to synthesize rhenium carbene bromido complexes in reasonable yields, when the lithiated thiophene is $\pi$-coordinated to a chromium tricarbonyl fragment acting as an electron-sink. ${ }^{3}$ The corresponding reaction of manganese pentacarbonyl bromide by lithium-halogen exchange proceeded to give novel $\sigma, \pi-\mathrm{Cr} / \mathrm{Mn}$ complexes with bridging thienyl and carboxythienyl ligands.

Alternatively, reversal of the reaction sequence shown in Scheme 1, by oxidative cleaving of the metal-metal bond in pre-prepared dimetal nonacarbonyl ethoxycarbene complexes with bromine, yields the desired monometal carbene bromido complexes. ${ }^{1}$

The interest in thiophene rings as useful Fischer carbene substituents lie in their planar structure, their electron excessive nature and ability to move charge by electron delocalization as a result of $\pi$-conjugation. ${ }^{4}$ Condensed thiophene ring derivatives, thieno[2,3-b]thiophene $\left(2,3-b-\mathrm{TTH}_{2}\right)$ and thieno[3,2-b]thiophene $\left(3,2-b-\mathrm{TTH}_{2}\right)$, (Fig. 1) bear the same general properties of thiophene, yet these substrates display subtle differences in their structural and electronic features. Inter-ring $\pi$-resonance effects are possible in 3,2-b- $\mathrm{TTH}_{2}$ (Fig. 1 (ii)), while electron delocalization in $2,3-b-\mathrm{TTH}_{2}$ is predominantly limited to the separate rings only (Fig. 1 (i)). In this study, the preparation of dirhenium(I) nonacarbonyl FCCs containing condensed thiophene substituents are reported, as well as the oxidative cleaving of the Re-Re bonds to yield the mononuclear bromido analogues. The effect of the replacement of a $-\operatorname{Re}(\mathrm{CO})_{5}$ fragment with a bromido ligand on the steric and electronic properties of the complexes is investigated using spectroscopic and electrochemical techniques, while a new synthetic route to access a novel tetracarbonyl rhenium(I) chlorido aminocarbene complex is reported.

\section{Results and discussion}

\section{Synthesis of complexes 1-5}

For both condensed thienothiophene substrates, 2,3-b- $\mathrm{TTH}_{2}$ and 3,2- $b-\mathrm{TTH}_{2}$, lithiation favours the $\alpha$-positions of thiophene. ${ }^{5}$ Facile mono- and dilithiation of 2,3-b- $\mathrm{TTH}_{2}$ and 3,2-b- $\mathrm{TTH}_{2}$, followed by reaction of the dirhenium decacarbonyl precursor and alkylation of

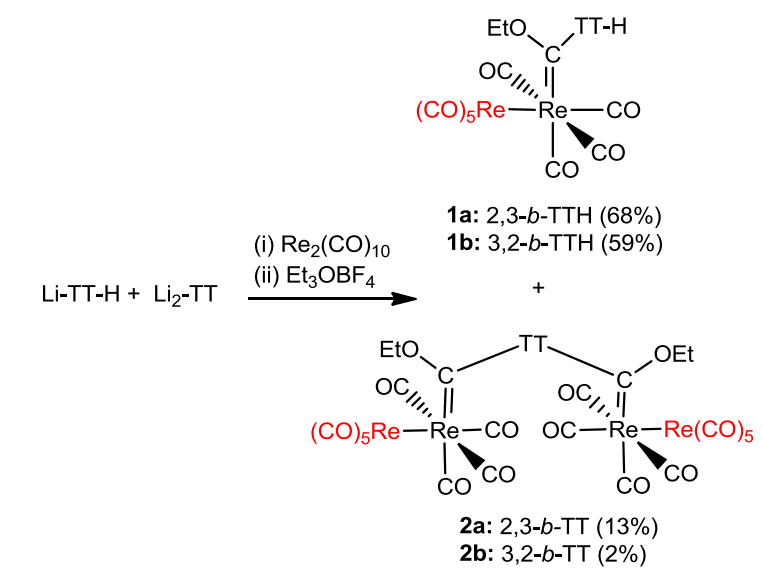

Scheme 2 Synthesis of di- and tetrarhenium mono- and bisethoxycarbene complexes containing thienothiphene substituents.

the resultant metal acylates yield the targeted mono- (1) and biscarbene (2) complexes of dirhenium nonacarbonyl (Scheme 2) in the classic synthetic methodology for Fischer carbene preparation using metal carbonyl precursors. However, low yields of the tetrarhenium biscarbene complexes $\mathbf{2} \mathbf{a}$ and $\mathbf{2} \mathbf{b}$ were obtained, in contrast to the group 6 metal carbonyl analogues. ${ }^{6}$ This low yield is ascribed to the steric congestion caused by the cis- coordination of the two $\operatorname{Re}(\mathrm{CO})_{5}$-fragments relative to the thienothiophene substrate during the second lithiation, rather than incomplete lithiation. Unlike manganese nonacarbonyl FCCs, where bulky carbene ligands readily occupy axial positions due to steric constraints $^{2 d}$ regardless of the electronic requirements, ${ }^{7}$ axial coordination of the carbene ligand trans to the Re-Re bond is rarely encountered. ${ }^{2}$ Previous studies in our group have shown that linking two dirhenium nonacarbonyl fragments by a 2,5bis(ethoxycarbene)thienylene spacer yields the eq,eq-isomer only, with marked deviation from planarity of the thiophene linker and a yield of only $5 \% .{ }^{2 c}$ Using an extended 5,2'-bithienyl linker results in less strain and higher yields of up to $60 \%$.

In an earlier study on the effect of oxidative cleavage of the metalmetal bonds of dimanganese nonacarbonyl FCCs with bromine, we have shown that the carbene ligands remain intact and the procedure affords a synthetic route to obtain the very scarce class of $\left[\mathrm{Mn}(\mathrm{CO}){ }_{4}\{\mathrm{C}(\mathrm{OEt}) \mathrm{R}\} \mathrm{Br}\right]\left(\mathrm{R}=\right.$ heteroaryl) complexes. ${ }^{1 a}$ Applying this methodology to rhenium FCCs results in good conversions when

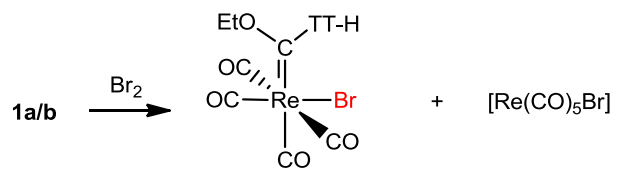

3a: $2,3-b-\mathrm{TT}(41 \%)$ 3b: $3,2-b-$ TT $(60 \%)$

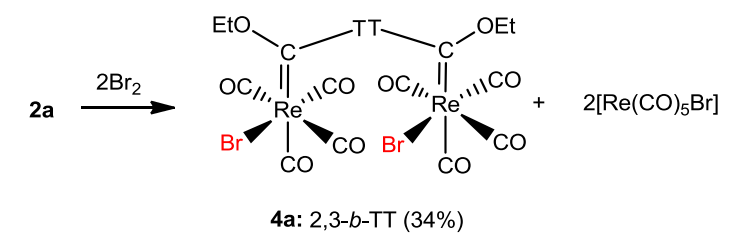

Scheme 3 Mono- and dirhenium bromido-carbene complexes $3 \mathbf{a}, \mathbf{3 b}$ and $4 \mathrm{a}$ obtained by Re-Re bond cleaving of $\mathbf{1 a}, \mathbf{1} \mathbf{b}$ and $\mathbf{2 a}$ with bromine 


$$
(\mathrm{OC})_{5} \mathrm{Re}=\left.\right|_{\mathrm{CO}} ^{\mathrm{OCO}}=\mathrm{Cl}_{\mathrm{CO}}^{\mathrm{Re}}-\mathrm{CO}
$$

1a: 2,3-b-TTH

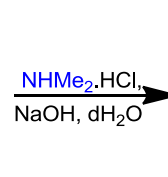

等

5a: $2,3-b-\mathrm{TTH}(56 \%)$

Scheme 4 Aminolysis of $1 \mathrm{a}$ using $\mathrm{NHMe}_{2} \cdot \mathrm{HCl}$ to produce $5 \mathrm{a}$.

reacting 1 with a slight excess of bromine in solvent hexane to yield the desired carbene bromido complexes $\mathbf{3 a}$ and $\mathbf{3 b}$ (Scheme 3 ). In the case of the tetrarhenium biscarbene complex $\mathbf{2 a}$, it was possible to cleave both Re-Re bonds with two equivalents of bromine affording novel mononuclear rhenium bromido tetracarbonyl fragments linked by a biscarbene thieno[2,3-b]thiophene unit (4a) in $34 \%$ yield.

The electronic carbene-stabilization effect of replacing the alkoxycarbene substituent with an amino-group is well-documented, ${ }^{10}$ but for comparative reasons it was decided to aminolyse FCC 1a with dimethylamine through a simple, yet effective method of aminolysis, in order to substitute the ethoxycarbene ligand with an aminocarbene ligand in $\mathbf{5 a}$ with increased $\pi$-donation from the amino-nitrogen lone pair towards the electrophilic carbene carbon. Many examples of dimethylaminocarbene complexes exist which are directly synthesised ${ }^{10 \mathrm{~g}}$ or synthesised through aminolysis reactions of alkoxycarbene complexes achieved by bubbling the commercially available dimethylamine gas through a solution or addition of a prepared THF solution. ${ }^{11}$ Dimethylamine in the gas form is expensive and cumbersome to use, while the THF solution is not ideal for handling or storing for long periods of time. The stability provided by the aromatic substituent of the carbene carbon allows for the aminolysis of the ethoxycarbene complexes in quantitative yields in an aqueous environment. Thus, a new method is presented in which dimethylamine is indirectly introduced for the aminolysis of the ethoxycarbene complexes. The ethoxycarbene complex 1a, dimethylamine hydrochloride (dimethylammonium chloride) and sodium hydroxide are suspended in THF (Scheme 4). A small amount of distilled water is added to the solution to ensure dissolution of all reagents. Upon solvation, dimethylamine is produced in situ in an acid-base reaction which leads to the rapid aminolysis of the ethoxycarbene complexes with dimethylamine. However, cleavage of the Re-Re bond occurs during the reaction to yield the tetracarbonyl chlorido amino-FCC 5 a in $56 \%$ yield, as well as the pentacarbonyl rhenium chloride cleavage product. Previous use of hydrochloric acid in a one-pot carbonyl ligand substitution reaction with $\operatorname{Re}_{2}(\mathrm{CO})_{10}$ has been reported to result in $\mathrm{Re}-\mathrm{Re}$ bond cleavage, although the reaction mechanism remains unexplored. ${ }^{12}$

\section{Spectroscopic characterization}

The carbene complexes were studied by NMR, IR and UV-Vis

Table 1 Selected bond lengths ( $(\AA)$ and angles $\left({ }^{\circ}\right)$ of $\mathbf{1 a}, \mathbf{1} \mathbf{b}, \mathbf{2} \mathbf{a}, \mathbf{3 a}, \mathbf{3 b}$ and $\mathbf{5 a}$; with the atom numbering scheme

\begin{tabular}{|c|c|c|c|c|c|c|}
\hline Compound & $1 a$ & $1 b$ & $2 a$ & $3 a$ & $3 b$ & $5 a$ \\
\hline \multicolumn{7}{|c|}{ Bond lengths } \\
\hline $\operatorname{Re}-\operatorname{Re}(\mathbf{1}, \mathbf{2}) / \operatorname{Br}(\mathbf{3}) / \mathrm{Cl}(\mathbf{5})$ & $3.1067(3)$ & $3.1020(2)$ & $3.0612(4)$ & $2.6322(4)$ & $2.6268(8)$ & $2.490(3)$ \\
\hline $\mathrm{Re}-\mathrm{C}_{\text {carb }}$ & $2.127(4)$ & $2.118(3)$ & $2.099(5)$ & $2.163(3)$ & $2.185(7)$ & $2.205(11)$ \\
\hline $\mathrm{C}_{\mathrm{carb}}-\mathrm{OEt} / \mathrm{NMe}_{2}$ & $1.332(5)$ & $1.335(4)$ & $1.313(6)$ & $1.319(4)$ & $1.289(8)$ & $1.290(13)$ \\
\hline $\mathrm{Re}-\mathrm{CO}_{4}$ trans to Ccarb & $1.976(4)$ & $1.981(4)$ & $1.973(6)$ & $1.991(3)$ & $1.987(8)$ & $1.963(15)$ \\
\hline $\mathrm{Re}-\mathrm{CO}_{4}$ trans to $\mathrm{Br} / \mathrm{Cl}$ & & & & $1.925(4)$ & $1.912(9)$ & $1.897(15)$ \\
\hline $\mathrm{Re}-\mathrm{CO}_{4}$ trans to Re-Re & $1.922(4)$ & $1.936(4)$ & $1.928(6)$ & & & \\
\hline $\mathrm{Re}-\mathrm{CO}_{4}$ trans to $\mathrm{CO}^{\mathrm{a}}$ & $1.990(4)$ & $1.991(4)$ & $1.988(6)$ & $2.008(3)$ & $2.015(8)$ & $2.007(14)$ \\
\hline $\mathrm{Re}-\mathrm{CO}_{5}$ trans to $\mathrm{CO}^{\mathrm{a}}$ & $2.000(4)$ & $1.998(4)$ & $1.994(6)$ & & & \\
\hline $\mathrm{Re}-\mathrm{CO}_{5}$ trans to Re-Re & $1.934(4)$ & $1.938(4)$ & $1.927(6)$ & & & \\
\hline $\mathrm{C}_{\mathrm{carb}}-\mathrm{C} 2$ & $1.457(6)$ & $1.459(5)$ & $1.464(7)$ & $1.441(4)$ & $1.439(10)$ & $1.485(13)$ \\
\hline \multicolumn{7}{|c|}{ Bond angles $\left({ }^{\circ}\right)$} \\
\hline $\mathrm{Re}-\mathrm{C}_{\text {carb }}-\mathrm{O} / \mathrm{N}$ & $131.0(3)$ & $130.2(2)$ & $123.4(4)$ & $127.6(2)$ & $129.3(5)$ & $128.6(8)$ \\
\hline $\mathrm{Re}-\mathrm{C}_{\text {Carb }}-\mathrm{C} 2$ & $123.8(3)$ & $125.5(2)$ & $125.3(4)$ & $125.1(2)$ & $123.0(5)$ & $115.4(7)$ \\
\hline $\mathrm{O} / \mathrm{N}-\mathrm{C}_{\text {carb }}-\mathrm{C2}$ & $105.0(3)$ & $104.0(3)$ & $111.3(5)$ & $107.3(3)$ & $107.3(6)$ & $116.0(9)$ \\
\hline \multicolumn{7}{|c|}{ Torsion angle $\left({ }^{\circ}\right)$} \\
\hline $\mathrm{Re}-\mathrm{C}_{\text {carb }}-\mathrm{C} 2-\mathrm{C} 3$ & $-30.1(6)$ & $31.2(6)$ & $27.9(12)$ & $4.4(5)$ & $-11.7(11)$ & $69(2)$ \\
\hline $\mathrm{O} / \mathrm{N}-\mathrm{C}_{\text {carb }}-\mathrm{C} 2-\mathrm{C} 3$ & $154.9(4)$ & $-154.5(4)$ & $-153.8(9)$ & $-176.8(3)$ & $175.3(7)$ & $-113(2)$ \\
\hline$C_{\text {trans to carb }}-\operatorname{Re}-\operatorname{Re}-C^{b}$ & $-30.6(2)$ & $31.8(2)$ & $-38.7(3)$ & & & \\
\hline$C 9-R e-R e-C^{b}$ & $-23.0(2)$ & $35.4(2)$ & $-37.1(3)$ & & & \\
\hline \multicolumn{7}{|c|}{ Angle between two mean planes $\left({ }^{\circ}\right)^{c}$} \\
\hline & 31.79 & 31.45 & 36.02 & 6.64 & 11.02 & 70.80 \\
\hline
\end{tabular}

${ }^{\mathrm{a}}$ Averaged bond length. ${ }^{\mathrm{b}}$ Smallest torsion angle. ${ }^{\mathrm{C}}$ The first mean plane drawn through $\mathrm{C} 2, \mathrm{C} 3, \mathrm{C} 4$ and C5, and the second through Re, $\mathrm{C}_{\text {carb }}$ and $\mathrm{O} / \mathrm{N}$. 
(a)

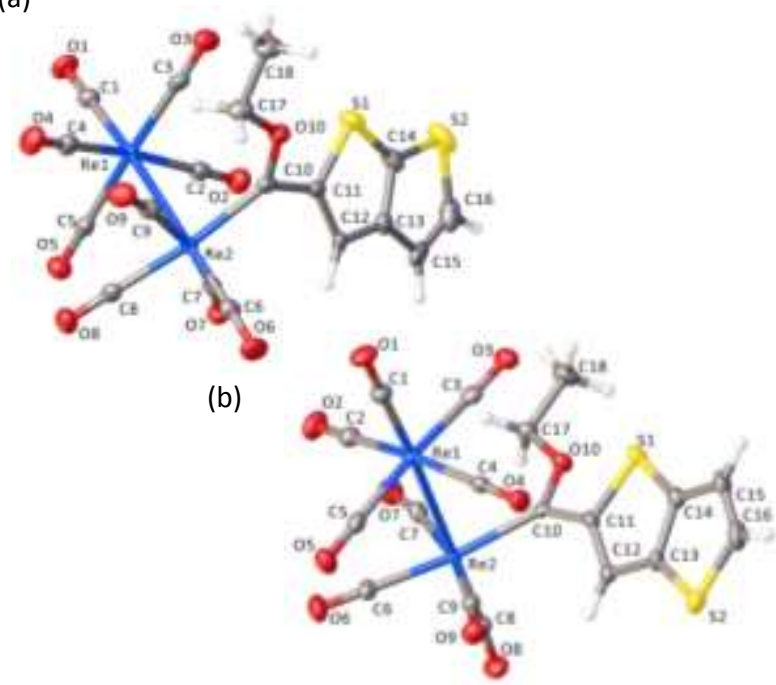

Fig. 2 ORTEP (ellipsoids at 55\% probability) diagrams of (a) $\mathbf{1 a}$ and (b) $\mathbf{1 b}$

spectroscopy, as well as mass spectrometry. A pattern of nine bands for the carbonyl stretching vibrations in the infrared spectra of 1 and 2 corresponds to equatorially substituted $\left.\left[\operatorname{Re}_{2}(\mathrm{CO})_{9} \mathrm{~L}\right]\right]^{8}$ Four bands of approximately equal intensity correspond to the vibrational modes of a cis- $\mathrm{M}(\mathrm{CO})_{4} \mathrm{~L}_{2}$ moiety ${ }^{9}$ and was observed for 3, 4a and 5a. The coordination geometry assignments are supported by the molecular structures obtained from the $\mathrm{X}$-ray crystal structure determinations of $\mathbf{1 a}, \mathbf{1 b}, \mathbf{2 a}, \mathbf{3 a}, \mathbf{3 b}$ and $\mathbf{5 a}$, respectively (vide infra). Coordination of a Fischer carbene carbon to a dirhenium nonacarbonyl fragment has a significant impact on the chemical shifts of $\mathrm{H}_{\beta}$ of the thiophene substituents in the ${ }^{1} \mathrm{H}$ NMR spectra. This proton resonance is shifted downfield due to the strong electron-withdrawing properties of the metal carbonyl carbene moiety. In addition, compared to non-condensed thiophene Re-FCC substituents previously reported, the $\beta$-protons are shifted to lower field, in the order thienyl < dithienyl < thieno[3,2-b]thienyl (1) $)=$ thieno[2,3-b]thienyl (1a) $(\delta 7.65<7.73<$ $7.98=7.99 \mathrm{ppm}) .^{2 c}$ The order correlates with the electron delocalization ability of the heteroaryl rings as a result of $\pi$ resonance effects of the thienyl substituents. For the biscarbene complexes the same trend in $\mathrm{H}_{\beta}$ resonances was observed for the thienyl substituents $(\delta 7.47$ (thienyl) $<7.71$ (dithienyl) $<7.84(2,3-b$ $\mathrm{TT}, \mathbf{2 b})<8.02(3,2-b-\mathrm{TT}, 2 \mathrm{a}) \mathrm{ppm}$.

Replacing a $-\operatorname{Re}(\mathrm{CO})_{5}$ fragment (1) by a $-\mathrm{Br}$ ligand (3) markedly affects the electronic features of the complex and shifts all the proton resonances in the ${ }^{1} \mathrm{H}$ NMR spectra to lower field (ESI Fig. S2, S7, S15 and S18). As for 1 and 2, increased ring delocalization perceived in the increasingly downfield $\mathrm{H}_{\beta}$ resonances compared to non-condensed thiophene carbene substituents - is still observed.
${ }^{2 c}$ The ${ }^{13} \mathrm{C}$ NMR spectra display carbene carbon chemical shifts for both the mono- and biscarbene complexes 1 and $\mathbf{2}$ and the analogous thienyl and dithienyl Re-FCCs in the range of $\delta$ 289-296 ppm, whereas the corresponding carbene bromido complexes $\mathbf{3 a}, \mathbf{b}$, display carbene carbon signals shifted significantly upfield $(\delta 260$ $274 \mathrm{ppm})$. The carbonyl carbons of the nonacarbonyl compounds 1 and 2 resonate as one broad peak in the ${ }^{13} \mathrm{C}$ NMR spectra and the chemical shifts are found more downfield (ca. $\delta 193 \mathrm{ppm}$ ) than those of the tetracarbonyl complexes, 3. For the tetracarbonyl ligands, three carbon signals are observed. The two cis-CO ligands' carbon atoms (trans with respect to each other) resonate as a single chemical shift of higher intensity, downfield relative to the other carbonyl C-atoms. The two lower intensity peaks observed more upfield represents the carbonyl carbon resonances trans to the carbene and the bromido ligands, respectively. The resonances of the thienothiophene ipso-carbons ( $\mathrm{C}_{\alpha}$-atoms) directly attached to the carbene carbons are similar, with values for the dirhenium carbene complexes 1 and 2 being shifted ( $\pm \delta 3 \mathrm{ppm}$ ) further downfield compared to the corresponding carbene bromido complexes, 3. Comparison of the $2 \mathrm{D}\left[{ }^{1} \mathrm{H},{ }^{13} \mathrm{C}\right] \mathrm{HSQC}$ spectra of 1 and $\mathbf{3}$, reveals that the most downfield thienothiophene proton $\mathrm{H}_{\beta}$ in $\mathbf{1}$ is bonded to the second most downfield aromatic carbon, $C_{\beta}$. However, for 3, both $\mathrm{H}_{\beta}$ and $\mathrm{C}_{\beta}$ are the most downfield thienothiophene resonances (ESI, Fig. S4, S9, S17 and S20), in all probability due to a $\mathrm{H} \cdots \mathrm{Br}$ interaction also observed in the crystal structures of $\mathbf{3 a}$ and $\mathbf{3 b}$ (vide infra).

Comparing the amino- and ethoxycarbene complexes $\mathbf{5 a}$ and $\mathbf{3 a}$, respectively, a significant upfield shift of $\mathrm{H}_{\beta}(\delta 6.70 \mathrm{ppm})$ and the carbene carbon resonance ( $\delta 242.1 \mathrm{ppm}$ ) of $\mathbf{5 a}$ is observed, in contrast to $H_{\beta}(\delta 8.81 \mathrm{ppm})$ and $C_{\text {carbene }}(\delta 270.2 \mathrm{ppm})$ of $3 a$. In addition, the steric bulk of the dimethyl-substituted amino-moiety results in the observance of four individual carbonyl carbon resonances observed in the ${ }^{13} \mathrm{C}$ NMR spectrum of $\mathbf{5 a}$, as well as the significant broadening of both the $\mathrm{H}_{\beta}$ and $\mathrm{C}_{\beta}$ resonances in both the ${ }^{1} \mathrm{H}$ and ${ }^{13} \mathrm{C}$ NMR spectra (Fig. S12 and S13).

\section{Structural studies}

Single crystals suitable for $\mathrm{X}$-ray diffraction studies of the dirhenium monocarbene complexes eq-[Re ${ }_{2}(\mathrm{CO})_{9}\{$ carbene $\left.\}\right]$ (1a and $\left.\mathbf{1 b}\right)$, the tetrarhenium biscarbene complex eq-,eq-[ $\operatorname{Re}_{4}(\mathrm{CO})_{18}\{\mu$-biscarbene $\left.\}\right]$ (2a) and monorhenium halido-carbene complexes cis$\left[\operatorname{Re}(\mathrm{CO})_{4}\{\right.$ carbene $\left.\} \mathrm{X}\right](\mathbf{3 a}, \mathbf{3 b}(\mathrm{X}=\mathrm{Br})$ and $\mathbf{5 a}(\mathrm{X}=\mathrm{Cl}))$ were grown from dichloromethane $\left(\mathrm{CH}_{2} \mathrm{Cl}_{2}\right)$ solutions layered with hexanes. The 


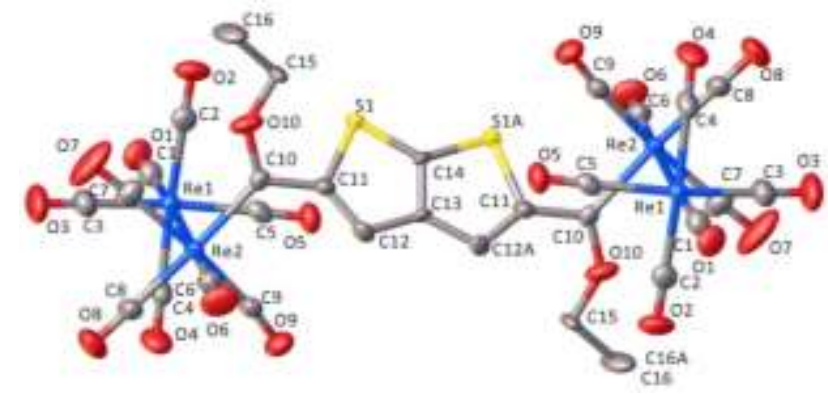

Fig. 3 ORTEP (ellipsoids at 55\% probability) diagrams of $\mathbf{2 a}$ (hydrogen atoms omitted for clarity).

(a)

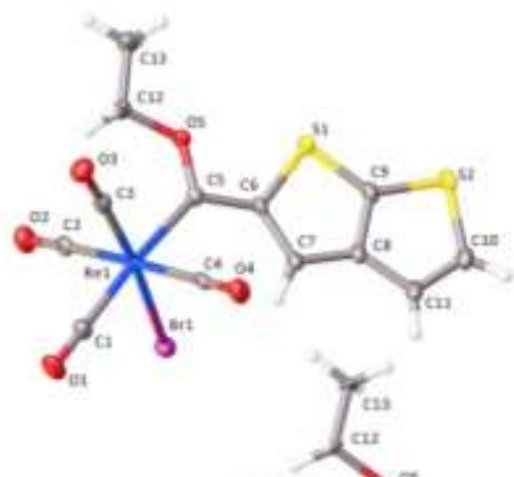

(b)

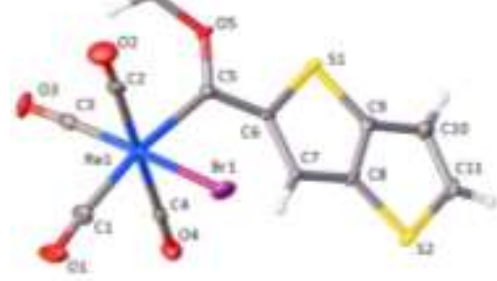

(c)

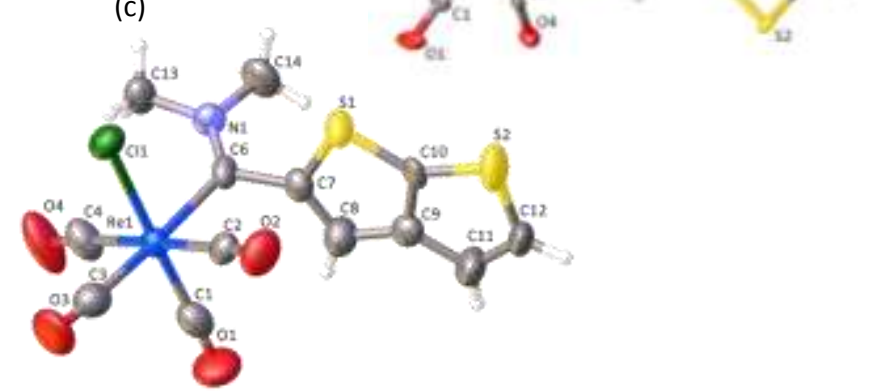

Fig. 4 ORTEP (ellipsoids at 55\% probability) diagrams of (a) 3a, (b) $\mathbf{3 b}$ and (c) $\mathbf{5 a}$

molecular structures are shown in Fig. 2-4 and selected bond lengths, angles and torsion angles are listed in Table 1 . The structures of $\mathbf{1 a}$ and $\mathbf{1} \mathbf{b}$ consist of two Re fragments, $-\operatorname{Re}(\mathrm{CO})_{5}$ and $\operatorname{Re}\{$ carbene $\}(\mathrm{CO})_{4}$, held together by Re-Re bonds, while in $\mathbf{3}$ the $\operatorname{Re}(\mathrm{CO})_{5}$ moiety is replaced by a $-\mathrm{Br}$ ligand. In $\mathbf{2}$, the thienothiophene substituent acts as a linker between two carbene functionalities forming a bridging ligand that combine two dirhenium units of $\mathbf{1}$ in a tetrarhenium complex assembly. For the dirhenium nonacarbonyl complexes $\mathbf{1}$ and $\mathbf{2}$, equatorial coordination of the carbene ligand (cis to the Re-Re bond) is confirmed, as well as cis disposition of the carbene ligand with respect to the bromido in the mononuclear complexes $3 \mathbf{a}, \mathbf{b}$. The equatorial carbonyl ligands around the $\operatorname{Re}-\operatorname{Re}$ bond, in the dirhenium complexes' structures, are in a staggered conformation. The torsion angles are larger than $23^{\circ}$ and increase from $\mathbf{1 a}<\mathbf{1} \mathbf{b}<$ 2a. The ethoxy substituents are orientated on the sulphur side of the rings (Z-isomer), except for $\mathbf{2} \mathbf{a}$ and $\mathbf{5 a}$ where these species lie across a centre of inversion and thus the thienothiophene rings are disordered by $50 \%$, with $50 \%$ rotated by $180^{\circ}$ with respect to the metal-carbene moieties. Longer Re- $\mathrm{C}_{\text {carbene }}$ bond lengths are observed when the $-\operatorname{Re}(\mathrm{CO})_{5}$ fragment is replaced with a bromido ligand (compare 3a, 2.163(3) $\AA$ and 3b, 2.185(7) $\AA$ with 1a, 2.127(4) $\AA$ and $\mathbf{1 b}, 2.118(3) \AA$, respectively). This observation seems to indicate an overall less electron-rich metal centre with the substitution of $-\operatorname{Re}(\mathrm{CO})_{5}$ with $-\mathrm{Br}$, due to the greater electronegativity of the $\mathrm{Br}$ atom, and a formal +1 oxidation state of the rhenium metal. As a consequence, compensation with regards to electrophilic carbene carbon stabilization by the carbene heteroatom substituent results in the shortening of $\mathrm{C}_{\text {carbene }}-\mathrm{OEt}$ bond distance in $\mathbf{3 a}$ and $\mathbf{3 b}$, compared to $\mathbf{1 a}$ and $\mathbf{1 b}$ (1.319(4) $\AA$, $1.289(8) \AA$ vs $1.332(5) \AA$, $1.335(4) \AA)$. Similar structural consequences were observed for the oxidative cleavage of the $\mathrm{Mn}$ $\mathrm{Mn}$ bonds in dimanganese nonacarbonyl FCCs with halogens. ${ }^{1 a}$

The torsion angles, $\mathrm{Re}-\mathrm{C}_{\text {carbene }}-\mathrm{C2}-\mathrm{C} 3$ and $\mathrm{O}-\mathrm{C}_{\text {carbene }}-\mathrm{C2}-\mathrm{C} 3$, serve as indicators that show how far the ethoxy and metal fragment is pushed out of the thienyl mean plane. In the case of $\mathbf{1 a}, \mathbf{1} \mathbf{b}$ and $\mathbf{2 a}$ these fragments are pushed out of the plane by approximately $30^{\circ}$, each in opposite directions, while for the monorhenium carbene bromido complexes $\mathbf{3 a}$ and $\mathbf{3 b}$ the angle never exceeds $12^{\circ}$, because of the much smaller and less bulky metalcarbonyl fragment.

For both $\mathbf{3 a}$ and $\mathbf{3 b}, \mathrm{Br} \cdots \mathrm{H} 3$ (the $\mathrm{H}_{\beta}$ thienothiophene hydrogen atom) intramolecular interactions are observed in the packing of the crystal lattices (ESI, Fig. S29); $2.809 \AA$ and $2.787 \AA$ for $3 \mathbf{a}$ and 3b, respectively. This could account for the downfield NMR shifts observed for these atoms in the corresponding NMR spectra (vide supra).

Similarly, as observed in the NMR spectra of $\mathbf{5 a}$, the X-ray structural studies demonstrate the increased electron-donating/carbene stabilization effect of the amino-group compared to the ethoxygroup of 3a. A longer Re- $C_{\text {carbene }}$ bond length of 2.205(11) $\AA$ for $\mathbf{5 a}$ is observed than the corresponding $\mathrm{Re}-\mathrm{C}_{\text {carbene }}$ bond length of 2.163(3) $\AA$ for 3a. This longer $R e-C_{\text {carbene }}$ bond length is accompanied by a $\mathrm{N}-\mathrm{C}_{\text {carbene }}$ bond length of $1.290(13) \AA$, indicative of a bond order greater than $\mathbf{1}$ in $\mathbf{5 a}$. 
Table 2 Cyclic voltammetry data (potentials $(V)$ and currents $(\mu \mathrm{A})$ ) for the two redox processes observed for 1-3 and $\mathbf{5 a}$

\begin{tabular}{|c|c|c|c|c|c|c|c|c|c|c|c|c|}
\hline & \multicolumn{2}{|c|}{$1 a$} & \multicolumn{2}{|c|}{$1 b$} & \multicolumn{2}{|c|}{$2 a$} & \multicolumn{2}{|c|}{$3 a$} & \multicolumn{2}{|c|}{$3 b$} & \multicolumn{2}{|c|}{$5 a$} \\
\hline & {$[\mathbf{1 a}]^{+1 / 0}$} & $\begin{array}{l}{[\mathrm{Re}=\mathrm{C} /} \\
\left.\mathrm{Re}-\mathrm{C}^{-}\right]\end{array}$ & {$[\mathbf{1 b}]^{+1 / 0}$} & $\begin{array}{l}{[\mathrm{Re}=\mathrm{C} /} \\
\left.-\mathrm{Re}-\mathrm{C}^{\prime}\right]\end{array}$ & {$[2 \mathrm{a}]^{+1 / 0}$} & $\begin{array}{l}{[\mathrm{Re}=\mathrm{C} /} \\
\left.\mathrm{Re}-\mathrm{C}^{\circ}\right]\end{array}$ & {$[\mathbf{3 a}]^{+1 / 0}$} & $\begin{array}{l}{[\mathrm{Re}=\mathrm{C} /} \\
\left.\mathrm{Re}-\mathrm{C}^{-}\right]\end{array}$ & {$[3 \mathbf{b}]^{+1 / 0}$} & $\begin{array}{l}{[\mathrm{Re}=\mathrm{C} /} \\
\left.\mathrm{Re}-\mathrm{C}^{-}\right]\end{array}$ & {$[5 \mathbf{a}]^{+1 / 0}$} & $\begin{array}{l}{[\mathrm{Re}=\mathrm{C} /} \\
\left.-\mathrm{Re}-\mathrm{C}^{\prime}\right]\end{array}$ \\
\hline$E_{p a}$ & 0.63 & -1.55 & 0.62 & -1.53 & $\begin{array}{l}0.69 \\
0.77^{a}\end{array}$ & - & $\begin{array}{l}1.33 \\
1.51^{a}\end{array}$ & -1.43 & 1.47 & -1.38 & 0.47 & - \\
\hline$E_{p c}$ & - & -1.67 & - & -1.62 & - & $\begin{array}{l}-1.48 \\
-1.66 \\
\end{array}$ & - & -1.52 & - & -1.47 & - & - \\
\hline$E^{\circ 1}$ & - & -1.61 & - & -1.58 & - & - & - & -1.48 & - & -1.43 & - & - \\
\hline$\Delta E_{p}$ & - & 0.12 & - & 0.09 & - & - & - & 0.09 & - & 0.09 & - & - \\
\hline$i_{p a}$ & 26.5 & 6.5 & 14 & 4 & $38,25^{a}$ & - & $58,76^{a}$ & 5 & 24 & 3 & 23 & - \\
\hline$i_{p c}$ & - & 30 & - & 10 & - & 11,4 & - & 13 & - & 10 & - & - \\
\hline
\end{tabular}

${ }^{a}$ Overlapping waves

\section{Cyclic voltammetry, UV-Vis-NIR and IR spectroelectrochemistry and DFT calculations}

The electrochemical properties of $\mathbf{1} \mathbf{a}, \mathbf{1} \mathbf{b}, \mathbf{2} \mathbf{a}, \mathbf{3 a}, \mathbf{5} \mathbf{a}$ and $\mathbf{3 b}$ were evaluated by cyclic voltammetry. In all cases, the cyclic voltammograms (measured at a glassy carbon electrode in $\mathrm{CH}_{2} \mathrm{Cl}_{2}$ ) show irreversible oxidation waves assigned to the rhenium metal centres ranging from ca. $0.62-0.77 \mathrm{~V}$ for the di- and tetranuclear FCCs 1 and 2a, to ca. 1.33-1.51 $\mathrm{V}$ for the mononuclear bromido FCCS 3 (Fig. 5 and ESI, Fig. S21-S26), (vs, $\mathrm{Ag} / \mathrm{Ag}^{+}$, referenced to the ferrocene/ferrocenium couple at $0 \mathrm{~V}$ ). The values obtained for 1-3 and $\mathbf{5 a}$ are summarized in Table $\mathbf{2}$. Single quasi-reversible reduction waves at negative potentials were observed for $\mathbf{1} \mathbf{a}, \mathbf{1} \mathbf{b}, \mathbf{3} \mathbf{a}$ and $\mathbf{3 b}$, while two overlapping, irreversible reduction events were observed for the biscarbene 2a. As expected, the CVs of $\mathbf{5 a}$ display less positive oxidation potentials $(0.47 \mathrm{~V})$ compared to the ethoxycarbene bromido analogue $\mathbf{3 a}$, as anticipated for the more electron-donating aminocarbene ligand. In addition, no reduction event was detectable within the workable potential window of $\mathrm{CH}_{2} \mathrm{Cl}_{2}$, as previously observed for other metal carbonyl aminoFCCs. ${ }^{10 c, e}$

The IR stretching frequencies of the CO ligands of $\mathbf{1 a}$ and $\mathbf{3 a}$ in the neutral and reduced state were measured by IR spectroelectrochemistry, and revealed a shift of the characteristic 9-band pattern for $1 \mathbf{a}$, and 4-band pattern for $\mathbf{3 a}$ to lower energies. For example, the $A^{\prime}{ }_{1}$ and $A^{\prime}{ }_{4} V_{\text {CO }}$ bands of $1 a$ at $2102 \mathrm{~cm}^{-1}$ and 1996 $\mathrm{cm}^{-1}$, shift to $2089 \mathrm{~cm}^{-1}$ and $1973 \mathrm{~cm}^{-1}$, respectively, for [1a]; while the characteristic $\mathrm{A}_{1}^{\left({ }^{(2)}\right.}$ band of $3 \mathrm{a}$ is shifted from $2002 \mathrm{~cm}^{-1}$ to 1973 $\mathrm{cm}^{-1}$ for [3a] (Fig S27 and S28). This shift of $13-29 \mathrm{~cm}^{-1}$ is consistent with the localization of the negative charge not on the Re-centre bonded directly to the carbonyl ligands (in which case a much greater shift of ca. $80-100 \mathrm{~cm}^{-1}$ is expected), ${ }^{13}$ but on a distal moiety bound to the metal carbonyl fragment. ${ }^{14}$ This is supported by the spin density calculations as visualized in Fig. S32 and Fig. S35.
Spin density analyses of the oxidized forms of $\mathbf{1 a}$ and $\mathbf{1} \mathbf{b},[\mathbf{1} \mathbf{a}]^{+}$and $[\mathbf{1 b}]^{+}$, respectively, and the reduced forms [1a] and [1b]', calculated with DFT (Fig S30-35) were used to confirm the redox events,
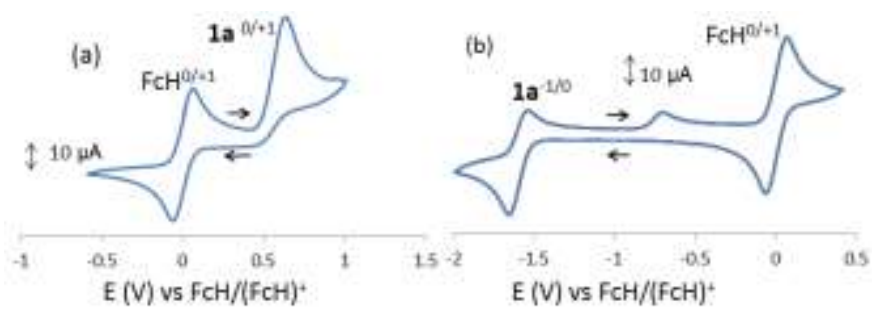

Fig. 5 Cyclic voltammograms of $1 \mathbf{a}$ at (a) positive potentials and (b) negative potentials, at a glassy carbon electrode, scan rate $0.1 \mathrm{Vs}^{-1}$ in $\mathrm{CH}_{2} \mathrm{Cl}_{2}$ with the internal standard marked as FcH.

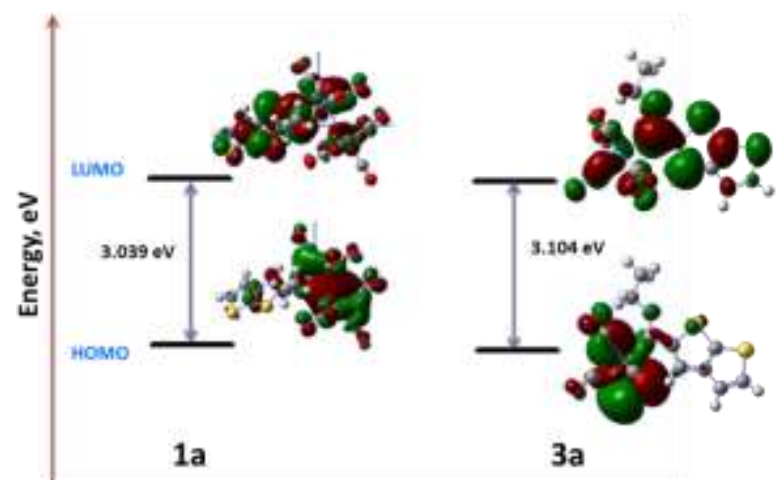

Fig. 6 Molecular Orbital representations and relative energy level diagrams of (a) 1a and (b) 3a as obtained from the DFT calculations (B3LYP/LANL2DZ).

namely a metal-based oxidation, and a carbene ligand-based reduction, as anticipated for FCCs of metal carbonyls. ${ }^{10}$ Visualisation of the HOMO and LUMO of 1a and 3a (Fig. 6) reveals the 
(i)

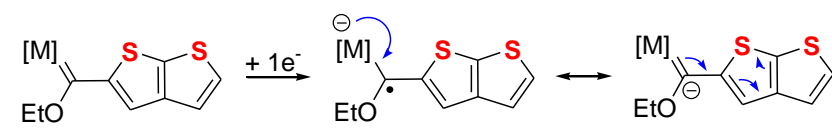

2,3-b-TTH-FCC (a)

(ii)

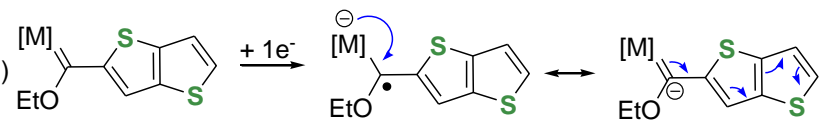

3,2-b-TTH-FCC (b)

Fig. 7 Stabilization via charge delocalization of radical anions generated by the $1 \mathrm{e}$ reduction of (i) 2,3-b-TTH-substituted FCCs (a), and (ii) 3,2-b-TTH-substituted FCCs (b).

localisation of the HOMO on the Re-carbonyl moieties, while the LUMO spreads across the $\mathrm{Re}=\mathrm{C}$ double bond and the conjugated heteroraryl (TTH) carbene substituent.

The use of the metal-based oxidation potentials as a probe for determining the electronic environment surrounding the central rhenium(I) metal is limited as a comparative tool, due to the irreversibility of the oxidation waves observed. However, it is clear that higher positive potentials are required for the $\operatorname{Re}(I)$ oxidation in the bromido FCCs $3 a$ and $\mathbf{3 b}(1.33 \mathrm{~V}, 1.51$ and $1.47 \mathrm{~V})$, where the rhenium is formally in oxidation state +1 , compared to the FCCs 1a and $\mathbf{1 b}(0.63 \mathrm{~V}$ and $0.62 \mathrm{~V})$ containing the Re-Re bond with an $\operatorname{Re}(\mathrm{CO})_{5}$ fragment instead of a halide ligand. For the tetrarhenium biscarbene complex 2a, the observance of both, two oxidation waves $\left(E_{p a}=0.69 \mathrm{~V}\right.$ and $\left.0.77 \mathrm{~V}\right)$, and two reduction waves $\left(E_{p c}=-\right.$ $1.48 \mathrm{~V}$ and $-1.66 \mathrm{~V}$ ) could be indicative of successive redox reactions leading to mixed-valent redox-active intermediates (for example, [2a] and [2a] ${ }^{2-}$, respectively). This observation may on the whole indicate the through-bond electronic communication between the molecular metal-carbene fragments, as supported by our spectroelectrochemistry studies (vide infra), rather than a split of the individual irreversible, oxidation/reduction waves due merely to an electrostatic effect. ${ }^{10 c, e}$

Redox potentials may not directly provide information on the electron-donating capacity of individual ligands, but is a good measure of the tendency of a system to acquire electrons and thus be reduced. Therefore, in our study, in the observed reduction potentials of complexes $\mathbf{1}$ and $\mathbf{3}$, more negative potentials are required for the one electron reduction of the $\mathrm{Re}=\mathrm{C}_{\text {carbene }}$ bond in the case of the dirhenium( 0 ) nonacarbonyl FCCS

1a and $\mathbf{1 b}\left(E^{\circ 1}=-1.61 \mathrm{~V}\right.$ and $-1.58 \mathrm{~V}$, respectively), than for the bromido rhenium(I) tetracarbonyl FCCs $3 \mathbf{a}$ and $\mathbf{3 b}\left(E^{\circ \prime}=-1.48 \mathrm{~V}\right.$ and $-1.43 \mathrm{~V}$, respectively). The more subtle effect of the carbene ligand condensed heteroaryl substituent, namely 2,3-b-TTH for FCCs 1a and $\mathbf{3 a}$, and $\mathbf{3}, \mathbf{2}-\mathbf{b}-\mathrm{TTH}$ for $\mathbf{1} \mathbf{b}$ and $\mathbf{3} \mathbf{b}$, can be deduced by analysing not only the reduction potentials (Table 2 ), but also the HOMOLUMO energy levels (band gaps, Fig. 6) of the corresponding compounds. In the case of $\mathbf{1 a}$ and $\mathbf{3 a}$, greater negative potentials are required for reduction than for $\mathbf{1} \mathbf{b}$ and $\mathbf{3 b}$, respectively. In the same way, for $\mathbf{1 a}$ compared to $\mathbf{1} \mathbf{b}$, a higher MO energy gap (3.039 eV compared to $2.976 \mathrm{eV}, \mathrm{ESI}$, Table S2) is calculated, which is also the case for $\mathbf{3 a}$ compared to $\mathbf{3 b}$ (3.104 eV vs. $2.980 \mathrm{eV}$ ). These relatively small energy differences were ascribed to the greater ability for the $\mathbf{b}$ series FCCs to stabilise the resultant radical anion
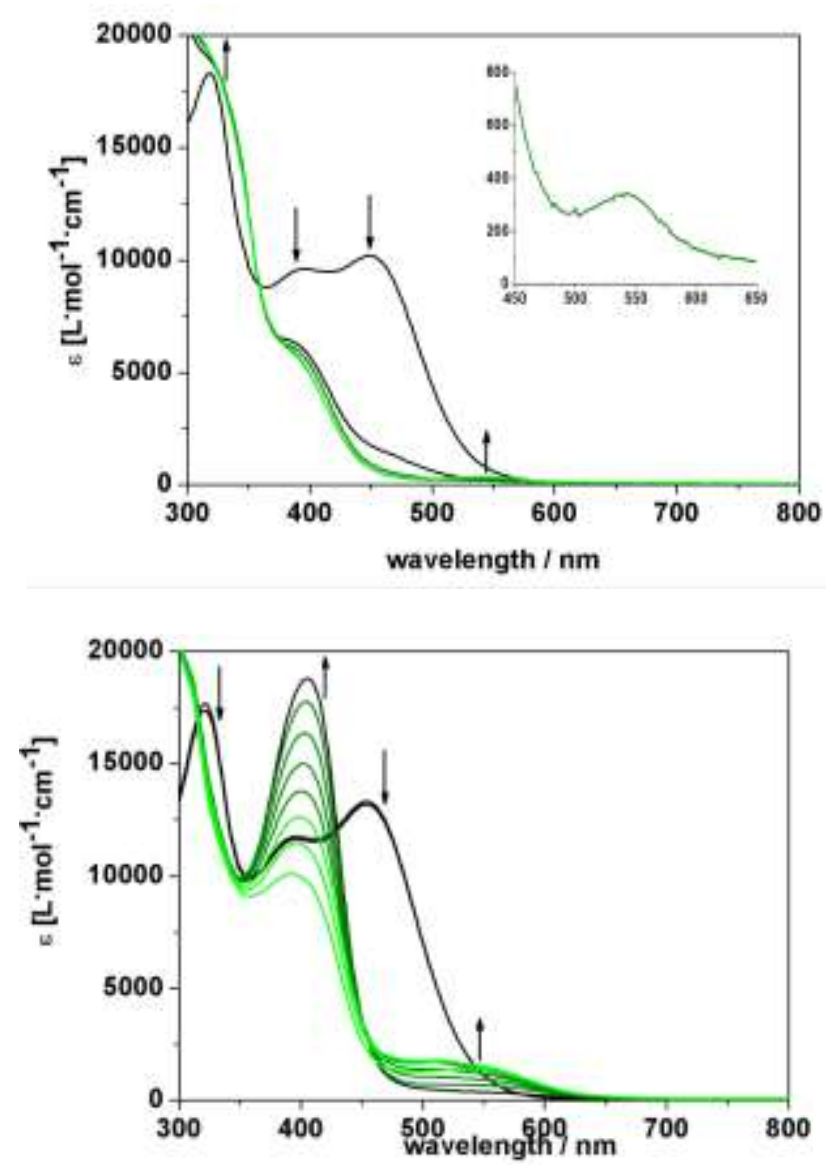

Fig 8. Changes in the UV-Vis absorption spectrum of 1a (top) and 1b (bottom) applied voltage range: -1.1 to $-1.4 \mathrm{~V}$. (Legend: Increasing cathodic voltages from black to light green)

following reduction. This is mainly caused by increased conjugation path length and inter-ring $\pi$-resonance which is not as prominent in the a series FCCs where electron delocalisation is predominantly restricted to one thiophene ring of the condensed rings (Fig. 7).

The electrochemical and $\mathrm{MO}$ analyses results prompted us to use UV-Vis-NIR spectroelectrochemistry (SEC) measurements for compounds $\mathbf{1 a}, \mathbf{1} \mathbf{b}, \mathbf{2} \mathbf{a}, \mathbf{3} \mathbf{a}$ and $\mathbf{3} \mathbf{b}$ to further investigate the effect of the condensed thienothiophene carbene substituents on the nature of the reduction of these FCCS. SEC is a hybrid analytical technique which can directly indicate the formation of charge transfer states in the molecule under study. The SEC measurements, upon reduction of molecules $\mathbf{1 a}$ and $\mathbf{1 b}$ (Fig. 8) at an applied potential range of -1.1 to $-1.4 \mathrm{~V}$, showed a weak absorption band centred around $540 \mathrm{~nm}$ with extinction coefficients below $5000 \mathrm{M}^{-1} \mathrm{~cm}^{-1}$ clearly indicating the formation of charge transfer species. Furthermore, the weak $540 \mathrm{~nm}$ feature appears with the disappearance of $450 \mathrm{~nm}$ band in $\mathbf{1 a}$ and rise of $420 \mathrm{~nm}$ band in $\mathbf{1 b}$. This is also evidenced from our time-dependent density functional theoretical (TD/DFT) calculations. The natural transition orbital (NTO) visualisations as obtained from the TD/DFT calculations (Fig. S30, S31) indicate that the $460 \mathrm{~nm}$ (493 $\mathrm{nm}$ as calculated) band corresponds to the HOMO-LUMO transition with $98 \%$ contribution to the absorption (Table S3) where the hole is spread on the Re-C end and the electron is delocalised on the TT side. The NTO and absorption analysis of the [1] $]^{-}$also indicates the rise of $420 \mathrm{~nm}$ 
band in $\mathbf{1 b}$ (Fig. S33, S34). The TD/DFT calculations reveal the new transitions at $\approx 540 \mathrm{~nm}$ to be a ligand-to-metal charge transfer (LMCT) with a minor $\pi-\pi$ transition within the TT moiety. In the case of 3, a weak absorption at $650 \mathrm{~nm}$ for $\mathbf{3 a}$ and $540 \mathrm{~nm}$ for $\mathbf{3 b}$ has been observed upon application of reducing voltage range -1.1 to $-1.4 \mathrm{~V}$ (Fig. S37, S38). Similarly, for 2a, a weak $560 \mathrm{~nm}$ band appears under reductive conditions (Fig. S36) at an expense of 450 $\mathrm{nm}$ absorption and a very weak absorption of $1600 \mathrm{~nm}$ with an absorption coefficient of $\approx 200 \mathrm{M}^{-1} \mathrm{~cm}^{-1}$. This rather weak transition can be attributed to the intervalence charge transfer (IVCT) between the Re centres as explained in the electrochemistry section. It is worth mentioning here that all of the compounds under study, underwent a charge transfer state via an isosbestic point (Fig. 8, S36, S37, S38) clearly indicating a direct electron transfer process. Nevertheless, the results obtained from cyclic voltammetry, $\mathrm{MO}$ calculations and spectroelectrochemistry suggest that the compounds under investigation undergo Re centred oxidations, while reduction results in the delocalisation of the negative charge on the $\mathrm{Re}=\mathrm{C}_{\text {carbene-TT moiety. }}$

\section{Experimental}

\section{General}

Thieno[2,3-b]thiophene, thieno[3,2-b]thiophene, bromine, $n$-BuLi (1.6 $\mathrm{M}$ solution in hexane) and dirhenium decacarbonyl were purchased from Sigma Aldrich and Strem Chemicals and used as received. Triethyloxonium tetrafluoroborate was prepared according to literature procedure. ${ }^{15}$ All operations were carried out using standard Schlenk techniques under an inert atmosphere of nitrogen or argon. Silica gel 60 (particle size $0.063-0.20 \mathrm{~mm}$ ) was used as resin for all column chromatography separations. Anhydrous THF (tetrahydrofuran) and hexane were distilled over sodium metal and benzophenone, and $\mathrm{CH}_{2} \mathrm{Cl}_{2}$ over $\mathrm{CaH}_{2}$ under $\mathrm{N}_{2}$ atmosphere. NMR spectra were recorded on Bruker AVANCE 500, Ultrashield Plus 400 AVANCE 3 and Ultrashield 300 AVANCE 3 spectrometers, at $25^{\circ} \mathrm{C}$, using $\mathrm{CDCl}_{3}$ as solvent. The ${ }^{1} \mathrm{H}$ NMR spectra were recorded at $500.139,400.13$ or $300.13 \mathrm{MHz}$, and the ${ }^{13} \mathrm{C} N M R$ spectra at $125.75,100.613$ or $75.468 \mathrm{MHz}$. The chemical shifts were referenced to deuterated chloroform $\left(\mathrm{CDCl}_{3}\right)$ signals at $7.26 \mathrm{ppm}$ for $\delta \mathrm{H}$ and $77.00 \mathrm{ppm}$ for $\delta \mathrm{C}$. Coupling constants are reported in $\mathrm{Hz}$. Numerical numbering of atoms for NMR spectral assignments is indicated in the ESI, Figure S1. Infrared spectroscopy was performed on a Bruker ALPHA FT-IR spectrophotometer with a $\mathrm{NaCl}$ cell, using hexane as solvent. Mass spectral analyses were performed on a Synapt G2 HDMS, by direct infusion at $10 \mu \mathrm{L} / \mathrm{min}$, with negative electron spray as ionization technique. Samples were made up in $100 \% \mathrm{MeOH}$ to an approximate concentration of 10 $\mu \mathrm{g} / \mathrm{mL}$. The $\mathrm{m} / \mathrm{z}$ values were measured in the range of $100-1500$. In the case of $\mathbf{5 a}$ the sample was made up in $100 \%$ acetonitrile and positive electron spray was used.

\section{Crystallography}

Single crystal diffraction data for $\mathbf{1 a}, \mathbf{1} \mathbf{b}, \mathbf{2} \mathbf{a}, \mathbf{3 a}, \mathbf{3} \mathbf{b}$ and $\mathbf{5 a}$ were collected at $150 \mathrm{~K}$ on a Bruker D8 Venture diffractometer with a kappa geometry goniometer and a Photon $100 \mathrm{CMOS}$ detector using a Mo-Ka l $\mu$ S.micro focus source. Data were reduced and scaled using SAINT. ${ }^{16}$ Absorption corrections were performed using
SADABS. ${ }^{16}$ The structures were solved by a novel duel-space algorithm using SHELXTS ${ }^{17}$ and were refined by full-matrix leastsquares methods based on $F^{2}$ using SHELXL. ${ }^{18}$ All non-hydrogen atoms were refined anisotropically. All hydrogen atoms were placed in idealized positions and refined using riding models. The CIF files for complexes $\mathbf{1 a}, \mathbf{1} \mathbf{b}, \mathbf{2} \mathbf{a}, \mathbf{3} \mathbf{a}, \mathbf{3} \mathbf{b}$ and $\mathbf{5 a}$ are available as Supporting Information.

\section{Cyclic voltammetry}

The $\mathrm{CVs}$ at a glassy carbon electrode in $\mathrm{CH}_{2} \mathrm{Cl}_{2}$ were recorded using a three-electrode cell. The reference electrode was a non-aqueous $\mathrm{Ag} / \mathrm{Ag}^{+}$electrode, separated by the test solution by a frit with fine porosity. Glassy carbon disc ( $3.0 \mathrm{~mm}$ diameter) was the working electrode and the counter electrode was a platinum wire. Measurement was done by a Metrohm $\mu$ Autolab type III potentiostat, using NOVA 2.0 electrochemistry software at scan rates of $100 \mathrm{mV} \cdot \mathrm{s}^{-1}$.

To a deoxygenated solution of $0.1 \mathrm{M}\left[\mathrm{N}^{n} \mathrm{Bu}_{4}\right]\left[\mathrm{PF}_{6}\right]$ (supporting electrolyte) in $\mathrm{HPLC}$ grade $\mathrm{CH}_{2} \mathrm{Cl}_{2}$, the test compound $(1.0 \mathrm{mM})$ and the internal standard, $1.0 \mathrm{mM}\left[\mathrm{Fe}\left(\eta^{5}-\mathrm{C}_{5} \mathrm{H}_{5}\right)_{2}\right]$ was added $\left(\mathrm{vs} \mathrm{Ag} / \mathrm{Ag}^{+}\right.$, $E^{\circ 1}=0 \mathrm{~V}$ for the ferrocene/ferrocenium couple).

\section{UV-Vis-NIR Spectroelectrochemistry}

Measurements were performed in $\mathrm{CH}_{2} \mathrm{Cl}_{2}$ containing $0.1 \mathrm{M}$ $\mathrm{N}^{n} \mathrm{Bu} \mathrm{u}_{4}\left[\mathrm{~B}\left(\mathrm{C}_{6} \mathrm{~F}_{5}\right)_{4}\right]$ at $2 \mathrm{mM}$ analyte concentrations within a OTTLE (optical transparent thin-layer electrochemistry) cell at $25^{\circ} \mathrm{C}$ in and with a Varian Cary 5000 spectrophotometer. ${ }^{19}$ The values obtained by deconvolution could be reproduced within $\varepsilon_{\max }=100 \mathrm{~L} \cdot \mathrm{mol}^{-1} \cdot \mathrm{cm}^{-}$ 1, $v_{\max }=50 \mathrm{~cm}^{-1}$, and $\Delta v_{1 / 2}=50 \mathrm{~cm}^{-1}$. Between the spectroscopic measurements the applied potentials have been increased stepwisely using step heights of $100,50,25$ or $20 \mathrm{mV}$. The spectral simulations were calculated using the least amount of gaussian functions to still achieve a reasonable fit of the simulation with the experimental spectrum.

\section{IR Spectroelectrochemistry}

Measurements were performed in $\mathrm{CH}_{2} \mathrm{Cl}_{2}$ containing $0.1 \mathrm{M}$ $\mathrm{N}^{n} \mathrm{Bu}_{4}\left[\mathrm{~B}\left(\mathrm{C}_{6} \mathrm{~F}_{5}\right)_{4}\right]$ at $2 \mathrm{mM}$ analyte concentrations within a OTTLE (optical transparent thin-layer electrochemistry) cell at $25^{\circ} \mathrm{C}$ with a Varian Cary 5000 spectrophotometer. Between the spectroscopic measurements the applied potentials have been increased stepwisely using step heights of $100,50,25$ or $20 \mathrm{mV}$.

\section{Computational details}

The geometry optimisation and time dependent DFT calculation were done on Gaussian $09^{20}$ program. The geometry optimizations, single point and TD/DFT calculations were performed using B3LYP/LANL2DZ basis sets. The molecular orbitals were visualized using Gaussview $5 .{ }^{21}$ The UV-Vis spectral visualisations and the spin populations were analysed using Gausssum $3.0^{22}$ and Chemissian 4.43 programs. $^{23}$

Preparation of $\left[\operatorname{Re}_{2}(\mathrm{CO})_{9}\{\mathrm{C}(\mathrm{OEt}) 2,3-b-\mathrm{TTH}\}\right]$
$\left[\left\{\operatorname{Re}_{2}(\mathrm{CO})_{9} \mathrm{C}(\mathrm{OEt})\right\}_{2}\{\mu-2,3-b-\mathrm{TT}\}_{2}\right] \quad(2 \mathrm{a}), \quad c i s-\left[\operatorname{Re}(\mathrm{CO}){ }_{4} \mathrm{Br}\{\mathrm{C}(\mathrm{OEt}) 2,3-b-\right.$
$\mathrm{TTH}\}](3 \mathrm{a})$, and $\left[\left\{\operatorname{Re}(\mathrm{CO})_{4} \mathrm{Br}(\mathrm{C}(\mathrm{OEt})\}_{2}\{\mu-2,3-b-\mathrm{TT}\}\right](4 \mathrm{a})\right.$


A solution of $0.07 \mathrm{~mL}(0.7 \mathrm{mmol})$ of thieno[2,3-b]thiophene in 15.0 $\mathrm{mL}$ of THF was treated with $0.75 \mathrm{~mL}(1.2 \mathrm{mmol})$ of $n$-BuLi at $-78^{\circ} \mathrm{C}$. After stirring for $30 \mathrm{~min}$., $\operatorname{Re}_{2}(\mathrm{CO})_{10}(0.65 \mathrm{~g}, 1.0 \mathrm{mmol})$ was added to the solution and stirred for a further $30 \mathrm{~min}$ in the cold and then allowed to reach room temperature over $40 \mathrm{~min}$. The solvent was removed under reduced pressure and the residue dissolved in 10 $\mathrm{mL}$ of $\mathrm{CH}_{2} \mathrm{Cl}_{2}$ and cooled to $-20^{\circ} \mathrm{C}$. The reaction mixture was treated with $0.23 \mathrm{~g}(1.2 \mathrm{mmol})$ of $\left[\mathrm{Et}_{3} \mathrm{O}\right]\left[\mathrm{BF}_{4}\right]$ in $\mathrm{CH}_{2} \mathrm{Cl}_{2}$ and subsequently allowed to reach room temperature. The reaction mixture was filtered through a small silica gel plug using $\mathrm{CH}_{2} \mathrm{Cl}_{2}$ and the solvent was removed under reduced pressure. After absorbing the reaction mixture on silica, it was dry loaded onto a silica gel column. The respective products ( $\mathbf{1} \mathbf{a}$ and $\mathbf{2} \mathbf{a}$ ) were separated by column chromatography using gradient elution with hexane and $\mathrm{CH}_{2} \mathrm{Cl}_{2}$. To synthesize $3 \mathbf{a}$ and $4 \mathrm{a}, 0.20 \mathrm{~g}(0.2 \mathrm{mmol}) \mathbf{1} \mathbf{a}$ and $0.10 \mathrm{~g}(0.1 \mathrm{mmol}) \mathbf{2 a}$ were each dissolved in hexane. Excess bromine dissolved in hexane were added dropwise to the solution while stirring, and allowed to react until no more colour change was observed. The solvent was removed in vacuo. Column chromatography was used to purify the products ( $3 a$ and $4 a$, respectively). Hexane was used as initial eluent and the polarity was gradually increased using $\mathrm{CH}_{2} \mathrm{Cl}_{2}$.

1a: Yield: $0.37 \mathrm{~g}(0.5 \mathrm{mmol}, 68 \%)$, red-orange crystals. $\lambda \max \left(\mathrm{CH}_{2} \mathrm{Cl}_{2}\right) / \mathrm{nm} 450\left(\varepsilon / \mathrm{dm}^{3} \mathrm{~mol}^{-1} \mathrm{~cm}^{-1} 14835\right), 390$ (12265), 320 (20995). $v_{\text {co }}\left(\right.$ hexane) $/ \mathrm{cm}^{-1} 2104 \mathrm{~m}\left(A_{1}^{\prime}\right), 2041 \mathrm{~s}\left(A_{2}^{\prime}\right), 2026 \mathrm{vw}\left(A_{3}^{\prime}\right)$, 2003vs $\left(A^{\prime \prime}{ }_{1}\right), 1995 \mathrm{vs}\left(A^{\prime}{ }_{4}\right), 1979 \mathrm{~m}\left(\mathrm{~A}^{\prime \prime}{ }_{2}\right), 1976 \mathrm{~m}\left(\mathrm{~A}_{5}^{\prime}\right), 1955 \mathrm{~s}\left(\mathrm{~A}_{6}^{\prime}\right)$, $1946 \mathrm{~m}\left(\mathrm{~A}^{\prime \prime}{ }_{3}\right) . \delta^{1} \mathrm{H}\left(400.13 \mathrm{MHz} ; \mathrm{CDCl}_{3} ; \mathrm{Me}_{4} \mathrm{Si}\right) 7.99(1 \mathrm{H}, \mathrm{s}, \mathrm{H} 4), 7.36$ $\left(1 \mathrm{H}, \mathrm{d},{ }^{3} \mathrm{~J}_{5^{\prime}, 4^{\prime}} 5.3, \mathrm{H} 5^{\prime}\right), 7.30\left(1 \mathrm{H}, \mathrm{d}^{3} \mathrm{~J}_{5^{\prime}, 4^{\prime}} 5.3, \mathrm{H} 4^{\prime}\right), 4.58\left(2 \mathrm{H}, \mathrm{q},{ }^{3} \mathrm{~J} 7.0\right.$, $\left.\mathrm{CH}_{2}\right), 1.63\left(3 \mathrm{H}, \mathrm{t},{ }^{3} \mathrm{~J} 7.0, \mathrm{CH}_{3}\right) \cdot \delta^{13} \mathrm{C}\left(100.613 \mathrm{MHz} ; \mathrm{CDCl}_{3} ; \mathrm{Me}_{4} \mathrm{Si}\right)$ 291.1 ( $\left.\mathrm{C}_{\text {carb }}\right), 192.3$ (br, $\left.\mathrm{Re}_{2}(\mathrm{CO})_{9}\right), 161.1$ (C5), 127.3 (C4), 146.3 (C3), $145.1(\mathrm{C} 2), 129.5\left(\mathrm{C}^{\prime}\right), 121.0\left(\mathrm{C}^{\prime}\right), 77.6\left(\mathrm{CH}_{2}\right), 14.6\left(\mathrm{CH}_{3}\right)$. $\mathrm{m} / \mathrm{z}\left(\mathrm{C}_{18} \mathrm{H}_{8} \mathrm{O}_{10} \mathrm{~S}_{2} \mathrm{Re}_{2}, 821.87 \mathrm{~g} / \mathrm{mol}\right) 820.9215(10 \%,[\mathrm{M}-\mathrm{H}]), 792.8709$ (100\%, [M-H-CO]'), 764.8759 (77\%, [M-H-2CO]').

2a: Yield: $0.13 \mathrm{~g}$, $(0.09 \mathrm{mmol}, 13 \%)$, red crystals. $\lambda \max \left(\mathrm{CH}_{2} \mathrm{Cl}_{2}\right) / \mathrm{nm}$ $476\left(\varepsilon / \mathrm{dm}^{3} \mathrm{~mol}^{-1} \mathrm{~cm}^{-1} 22754\right), \quad 390 \quad(16638), \quad 315 \quad$ (35716). $\mathrm{v}_{\text {co }}$ (hexane) $/ \mathrm{cm}^{-1} 2105 \mathrm{~m}\left(\mathrm{~A}_{1}^{\prime}\right), 2044 \mathrm{~s}\left(\mathrm{~A}_{2}^{\prime}\right), 2015 \mathrm{vw}\left(\mathrm{A}_{3}^{\prime}\right), 2001 \mathrm{vs}$ $\left(A^{\prime \prime}{ }_{1}\right), 1998 \mathrm{vs}\left(A_{4}^{\prime}\right), 1982 \mathrm{~m}\left(A^{\prime \prime}{ }_{2}\right), 1976 \mathrm{~m}\left(\mathrm{~A}_{5}^{\prime}\right), 1960 \mathrm{~s}\left(\mathrm{~A}_{6}^{\prime}\right), 1948 \mathrm{~m}$ $\left(\mathrm{A}^{\prime \prime}{ }_{3}\right) . \delta^{1} \mathrm{H}\left(300.13 \mathrm{MHz} ; \mathrm{CDCl}_{3} ; \mathrm{Me}_{4} \mathrm{Si}\right) 8.02(2 \mathrm{H}, \mathrm{s}, \mathrm{H} 4), 4.54(4 \mathrm{H}, \mathrm{q}$, 3 7.0, $\left.\mathrm{CH}_{2}\right), 1.64\left(6 \mathrm{H}, \mathrm{t},{ }^{3}\right.$ J 7.0, $\left.\mathrm{CH}_{3}\right) . \delta^{13} \mathrm{C}\left(75.468 \mathrm{MHz} ; \mathrm{CDCl}_{3} ; \mathrm{Me}_{4} \mathrm{Si}\right)$ $291.6\left(\mathrm{C}_{\text {carb }}\right)$, n.o. $\left(\operatorname{Re}_{2}(\mathrm{CO})_{9}\right), 162.5$ (C5), 127.4 (C4), 144.9 (C3), 149.4 (C2), $78.1\left(\mathrm{CH}_{2}\right), 14.5\left(\mathrm{CH}_{3}\right) . \mathrm{m} / \mathrm{z}\left(\mathrm{C}_{30} \mathrm{H}_{12} \mathrm{O}_{20} \mathrm{~S}_{2} \mathrm{Re}_{4}, 1503.76\right.$ $\mathrm{g} / \mathrm{mol}) 1502.7466\left(32 \%,[\mathrm{M}-\mathrm{H}]^{-}\right), 1474.7036$ (48\%, [M-H-CO]).

3a: Yield: $0.06 \mathrm{~g}(0.1 \mathrm{mmol}, 41 \%)$, yellow crystals. $\lambda \max \left(\mathrm{CH}_{2} \mathrm{Cl}_{2}\right) / \mathrm{nm}$ $435\left(\varepsilon / \mathrm{dm}^{3} \mathrm{~mol}^{-1} \mathrm{~cm}^{-1} \quad 8520\right), \quad 381 \quad(16372), \quad 335 \quad$ (7395). $\mathrm{v}_{\text {co }}($ hexane $) / \mathrm{cm}^{-1} 2026 \mathrm{~m}\left(\mathrm{~A}_{1}{ }^{(1)}\right)$, 2001s $\left(\mathrm{A}_{1}{ }^{(2)}\right), 1986 \mathrm{~m}\left(\mathrm{~B}_{1}\right), 1943 \mathrm{~s}$ $\left(\mathrm{B}_{2}\right) . \delta^{1} \mathrm{H}\left(400.13 \mathrm{MHz} ; \mathrm{CDCl}_{3} ; \mathrm{Me}_{4} \mathrm{Si}\right) 8.81(1 \mathrm{H}, \mathrm{s}, \mathrm{H} 4), 7.42(1 \mathrm{H}, \mathrm{d}$, $\left.{ }^{3} J_{5^{\prime}, 4^{\prime}} 5.4, \mathrm{H} 5^{\prime}\right), 7.40\left(1 \mathrm{H}, \mathrm{d},{ }^{3} J_{5^{\prime}, 4^{\prime}} 5.4, \mathrm{H} 4^{\prime}\right), 5.31\left(2 \mathrm{H}, \mathrm{q}^{3}{ }^{3} \mathrm{~J} 7.0, \mathrm{CH}_{2}\right)$, $1.69\left(3 \mathrm{H}, \mathrm{t},{ }^{3} \mathrm{~J} 7.0, \mathrm{CH}_{3}\right) . \delta^{13} \mathrm{C}\left(100.613 \mathrm{MHz} ; \mathrm{CDCl}_{3} ; \mathrm{Me}_{4} \mathrm{Si}\right) 270.2$ $\left(\mathrm{C}_{\text {carb }}\right), 185.6\left(\left(\operatorname{Re}(\mathrm{CO})_{4}\right)_{c i s}\right), 184.3$ and $184.1\left(\left(\operatorname{Re}(\mathrm{CO})_{4}\right)_{\text {trans }}\right.$ to $C 5$ and $\left.\mathrm{Br}\right)$, 158.3 (C5), 140.8 (C4), 147.7 (C3), 152.1 (C2), 130.6 (C5'), 121.9 (C4'), $79.1\left(\mathrm{CH}_{2}\right), 15.0\left(\mathrm{CH}_{3}\right) . \mathrm{m} / z\left(\mathrm{C}_{13} \mathrm{H}_{8} \mathrm{O}_{5} \mathrm{~S}_{2} \mathrm{ReBr}, 573.86 \mathrm{~g} / \mathrm{mol}\right)$ 488.8381 (3\%, [M-3CO-H] ) , 460.8229 (18\%, [M -4CO-H]).

4a: Yield: $0.02 \mathrm{~g}$ (0.02 mmol, 34\%), orange crystals. $u_{\text {co }}$ (hexane)/cm ${ }^{1} 2033 \mathrm{~s}\left(\mathrm{~A}_{1}{ }^{(1)}\right)$, 2021s $\left(\mathrm{A}_{1}{ }^{(2)}\right), 2004 \mathrm{~s}\left(\mathrm{~B}_{1}\right), 1945 \mathrm{~s}\left(\mathrm{~B}_{2}\right) . \delta^{1} \mathrm{H}(400.13 \mathrm{MHz}$; $\left.\mathrm{CDCl}_{3} ; \mathrm{Me}_{4} \mathrm{Si}\right) 8.97(2 \mathrm{H}, \mathrm{s}, \mathrm{H} 4), 5.38\left(4 \mathrm{H}, \mathrm{q},{ }^{3} \mathrm{~J} 7.0, \mathrm{CH}_{2}\right), 1.72(6 \mathrm{H}, \mathrm{t}$, 3J 7.0, $\left.\mathrm{CH}_{3}\right) . \delta^{13} \mathrm{C}\left(100.613 \mathrm{MHz} ; \mathrm{CDCl}_{3} ; \mathrm{Me}_{4} \mathrm{Si}\right) 274.2$ ( $\left.\mathrm{C}_{\text {carb }}\right), 185.0$
$\left(\left(\operatorname{Re}(\mathrm{CO})_{4}\right)_{\text {cis }}\right), 183.8$ and $183.5\left(\left(\operatorname{Re}(\mathrm{CO})_{4}\right)_{\text {trans to }} \mathrm{C5}_{\text {and }} \mathrm{Br}\right), 159.7(\mathrm{C} 5)$, 142.0 (C4), 147.1 (C3), n.o. (C2), $80.1 \quad\left(\mathrm{CH}_{2}\right), \quad 15.0 \quad\left(\mathrm{CH}_{3}\right)$. $\mathrm{m} / z\left(\mathrm{C}_{20} \mathrm{H}_{12} \mathrm{O}_{10} \mathrm{~S}_{2} \mathrm{Re}_{2} \mathrm{Br}_{2}, 1007.74 \mathrm{~g} / \mathrm{mol}\right) 894.6707$ (15\%, [M-4CO-H] ), 866.6738 (23\%, [M-5CO-H]), 838.6751 (55\%, [M-6CO-H] ).

\section{Preparation of $c i s-\left[\operatorname{Re}(\mathrm{CO})_{4} \mathrm{Cl}\left\{\mathrm{C}\left(\mathrm{NMe}_{2}\right) 2,3-b-\mathrm{TTH}\right\}\right]$ (5a)}

Compound 5a was obtained by reacting $1.13 \mathrm{~g}$ (1.4 mmol) of 1a, dissolved in $10 \mathrm{~mL}$ THF, with $1.14 \mathrm{~g}$ of dimethylamine hydrochloride (14.0 mmol) and $0.56 \mathrm{~g}$ of sodium hydroxide $(14.0 \mathrm{mmol})$. Distilled water was added dropwise until all the suspended salts were dissolved and a yellow colour was observed. The reaction was followed with TLC until all the starting material had reacted. The $\mathrm{dH}_{2} \mathrm{O}$ was removed using a separatory funnel and the THF layer dried over $\mathrm{MgSO}_{4}$, filtered and the solvent was reduced in vacuo. The product was purified using column chromatography starting with hexane and then increasing the polarity with $\mathrm{CH}_{2} \mathrm{Cl}_{2}$.

5a: Yield: $0.41 \mathrm{~g}(0.78 \mathrm{mmol}, 56 \%)$, yellow crystals. $\mathrm{v}_{\mathrm{CO}}\left(\mathrm{CH}_{2} \mathrm{Cl}_{2}\right) / \mathrm{cm}^{-1}$ $2038 \mathrm{~m}\left(\mathrm{~A}_{1}{ }^{(1)}\right)$, 1993s $\left(\mathrm{A}_{1}{ }^{(2)}\right)$, 1984s $\left(\mathrm{B}_{1}\right), 1929 \mathrm{~m}\left(\mathrm{~B}_{2}\right) . \delta^{1} \mathrm{H}(400.13$ $\left.\mathrm{MHz} ; \mathrm{CDCl}_{3} ; \mathrm{Me}_{4} \mathrm{Si}\right) 7.31\left(1 \mathrm{H}, \mathrm{d}^{3}{ }^{3} \mathrm{~J}_{5^{\prime}, 4^{\prime}} 5.2, \mathrm{H} 5^{\prime}\right), 7.19\left(1 \mathrm{H}, \mathrm{d}^{3} \mathrm{~J}_{5^{\prime}, 4^{\prime}} 5.2\right.$, $\left.\mathrm{H} 4^{\prime}\right), 6.70\left(1 \mathrm{H}, \mathrm{s}\right.$ br, H4), $3.72\left(3 \mathrm{H}, \mathrm{s}, \mathrm{NCH}_{3}\right), 3.27\left(3 \mathrm{H}, \mathrm{s}, \mathrm{NCH}_{3}\right)$. $\delta^{13} \mathrm{C}\left(100.613 \mathrm{MHz} ; \mathrm{CDCl}_{3} ; \mathrm{Me}_{4} \mathrm{Si}\right) 242.1$ (C $\left.\mathrm{C}_{\text {carb }}\right), 197.8,194.9,193.7$, $189.1\left(\operatorname{Re}(\mathrm{CO})_{4}\right), 157.0(\mathrm{C} 5), 112.3(\mathrm{C} 4), 145.8$ (C3), $136.4(\mathrm{C} 2), 128.4$ (C5'), 120.2 (C4'), 53.5 and $46.9\left(\mathrm{CH}_{3}\right) \cdot \mathrm{m} / \mathrm{z}\left(\mathrm{C}_{13} \mathrm{H}_{9} \mathrm{ClNO}_{4} \mathrm{ReS}_{2}, 528.98\right.$ $\mathrm{g} / \mathrm{mol}) 493.9702\left(18 \%,[\mathrm{M}-\mathrm{Cl}]^{+}\right), 479.0067\left(14 \%,\left[\mathrm{M}-\mathrm{Cl}-\mathrm{CH}_{3}\right]^{+}\right)$, $465.9721\left(24 \%,[\mathrm{M}-\mathrm{Cl}-\mathrm{CO}]^{+}\right)$.

\section{Preparation of $\left[\operatorname{Re}_{2}(\mathrm{CO})_{9}\{\mathrm{C}(\mathrm{OEt}) 3,2-b-\mathrm{TTH}\}\right] \quad$ (1b), $\left[\left\{\operatorname{Re}_{2}(\mathrm{CO}){ }_{9} \mathrm{C}(\mathrm{OEt})\right\}_{2}\{\mu-3,2-b-\mathrm{TT}\}\right] \quad(2 \mathrm{~b}), \quad$ cis- $\left[\operatorname{Re}(\mathrm{CO}){ }_{4} \mathrm{Br}\{\mathrm{C}(\mathrm{OEt}) 3,2-b-\right.$ $\mathrm{TTH}\}]$ (3b), and $\left[\left\{\operatorname{Re}(\mathrm{CO}){ }_{4} \mathrm{Br}(\mathrm{C}(\mathrm{OEt})\}_{2}\{\mu-3,2-b-\mathrm{TT}\}\right](4 \mathrm{~b})\right.$}

$1.88 \mathrm{~mL}$ of $n$-BuLi $(3.0 \mathrm{mmol})$ was added to $0.21 \mathrm{~g}(1.5 \mathrm{mmol})$ of thieno[3,2-b]thiophene dissolved in $20 \mathrm{ml}$ of THF at $-50^{\circ} \mathrm{C}$. After $1 \mathrm{~h}$, $1.96 \mathrm{~g}(3.0 \mathrm{mmol})$ of $\operatorname{Re}_{2}(\mathrm{CO})_{10}$ was added to the reaction mixture. The solution stirred for 15 minutes at $-78^{\circ} \mathrm{C}$ and was allowed to stir at room temperature for 40 minutes. The solvent was reduced in vacuo. The residue was dissolved in $10 \mathrm{ml}$ of $\mathrm{CH}_{2} \mathrm{Cl}_{2}$ and cooled to $30^{\circ} \mathrm{C}$, followed by treatment with $0.95 \mathrm{~g}(5.0 \mathrm{mmol})$ of $\left[\mathrm{Et}_{3} \mathrm{O}\right]\left[\mathrm{BF}_{4}\right]$ in $\mathrm{CH}_{2} \mathrm{Cl}_{2}$. The reaction mixture was allowed to reach room temperature. Most of the solvent was removed in vacuo, and the sample was wet loaded. Separation was done with a silica column, starting with hexane and gradually increasing the polarity of the solvent by adding $\mathrm{CH}_{2} \mathrm{Cl}_{2}$, resulting in the isolation of the respective products $\mathbf{1} \mathbf{b}$ and $\mathbf{2} \mathbf{b}$. To synthesize $\mathbf{3 b}, 0.36 \mathrm{~g}(0.4 \mathrm{mmol})$ of $\mathbf{1} \mathbf{b}$ was dissolved in hexane. Excess bromine dissolved in hexane was added dropwise to the solution while the mixture was stirred. The reaction was terminated as soon as the colour of the solution lightened, by removing the solvent in vacuo. Column chromatography was used to purify $\mathbf{3} \mathbf{b}$, with hexane as initial eluent and the polarity was gradually increased using $\mathrm{CH}_{2} \mathrm{Cl}_{2}$.

1b: Yield: $0.73 \mathrm{~g}(0.89 \mathrm{mmol}, 59 \%)$, red-orange crystals. $\lambda \max \left(\mathrm{CH}_{2} \mathrm{Cl}_{2}\right) / \mathrm{nm} 455\left(\varepsilon / \mathrm{dm}^{3} \mathrm{~mol}^{-1} \mathrm{~cm}^{-1} 14165\right), 395$ (12546), 322 (18907). $v_{\text {co }}$ (hexane) $/ \mathrm{cm}^{-1} 2103 \mathrm{~m}\left(A_{1}^{\prime}\right), 2041 \mathrm{~s}\left(A_{2}^{\prime}\right), 2025 \mathrm{vw}\left(A_{3}^{\prime}\right)$, 2003vs $\left(A^{\prime \prime}{ }_{1}\right), 1994 v s\left(A_{4}^{\prime}\right), 1978 m\left(A^{\prime \prime}\right), 1976 m\left(A_{5}^{\prime}\right), 1955 s\left(A_{6}^{\prime}\right)$, $1945 \mathrm{~m}\left(\mathrm{~A}^{\prime \prime}{ }_{3}\right) . \delta^{1} \mathrm{H}\left(400.13 \mathrm{MHz} ; \mathrm{CDCl}_{3} ; \mathrm{Me}_{4} \mathrm{Si}\right) 7.98(1 \mathrm{H}, \mathrm{s}, \mathrm{H} 4), 7.61$ $\left(1 \mathrm{H}, \mathrm{d}^{3}{ }^{3} \mathrm{~J}_{5^{\prime}, 4^{\prime}} 5.3, \mathrm{H} 5^{\prime}\right), 7.24\left(1 \mathrm{H}, \mathrm{d},{ }^{3} \mathrm{~J}_{5^{\prime}, 4^{\prime}} 5.3, \mathrm{H} 4^{\prime}\right), 4.57\left(2 \mathrm{H}, \mathrm{q},{ }^{3} \mathrm{~J} 7.0\right.$, $\left.\mathrm{CH}_{2}\right), 1.62\left(3 \mathrm{H}, \mathrm{t},{ }^{3} \mathrm{~J} 7.0, \mathrm{CH}_{3}\right) \cdot \delta^{13} \mathrm{C}\left(100.613 \mathrm{MHz} ; \mathrm{CDCl}_{3} ; \mathrm{Me}_{4} \mathrm{Si}\right)$ $292.3\left(\mathrm{C}_{\mathrm{carb}}\right), 193.3\left(\mathrm{br}, \mathrm{Re}_{2}(\mathrm{CO})_{9}\right), 159.6(\mathrm{C} 5), 126.2(\mathrm{C} 4), 144.7$ (C3), 139.4 (C2), 132.8(C5'), 119.8 (C4'), $77.6\left(\mathrm{CH}_{2}\right), 14.6\left(\mathrm{CH}_{3}\right)$. 
$\mathrm{m} / z\left(\mathrm{C}_{18} \mathrm{H}_{8} \mathrm{O}_{10} \mathrm{~S}_{2} \mathrm{Re}_{2}, 821.87 \mathrm{~g} / \mathrm{mol}\right) 820.8818$ (39\%, [M-H]) $), 792.8371$ (100\%, [M-H-CO]"), 764.8448 (47\%, [M-H-2CO]).

2b: Yield: $0.039 \mathrm{~g}$, $(0.025 \mathrm{mmol}, 2 \%)$, purple crystals. $\delta^{1} \mathrm{H}(300.13$ $\mathrm{MHz} ; \mathrm{CDCl}_{3}$; $\left.\mathrm{Me}_{4} \mathrm{Si}\right) 7.84(2 \mathrm{H}, \mathrm{s}, \mathrm{H} 4), 4.52\left(4 \mathrm{H}, \mathrm{q},{ }^{3} \mathrm{~J} 7.0, \mathrm{CH}_{2}\right), 1.64$ $\left(6 \mathrm{H}, \mathrm{t},{ }^{3} \mathrm{~J} 7.0, \mathrm{CH}_{3}\right)$.

3b: Yield: $0.14 \mathrm{~g}(0.24 \mathrm{mmol}, 60 \%)$, yellow-orange crystals. $\lambda \max \left(\mathrm{CH}_{2} \mathrm{Cl}_{2}\right) / \mathrm{nm} 442\left(\varepsilon / \mathrm{dm}^{3} \mathrm{~mol}^{-1} \mathrm{~cm}^{-1} 7685\right), 395$ (19827), 343 (7265). $v_{\text {co }}$ (hexane) $/ \mathrm{cm}^{-1} 2101 \mathrm{~m}\left(A_{1}{ }^{(1)}\right), 2026 \mathrm{~m}\left(A_{1}{ }^{(2)}\right), 2001 \mathrm{~s}\left(B_{1}\right)$, $1943 \mathrm{~m}\left(\mathrm{~B}_{2}\right) . \delta^{1} \mathrm{H}\left(400.13 \mathrm{MHz} ; \mathrm{CDCl}_{3} ; \mathrm{Me}_{4} \mathrm{Si}\right) 8.87\left(1 \mathrm{H}, \mathrm{d},{ }^{5} J_{4,4^{\prime}} 0.5\right.$, H4), $7.86\left(1 \mathrm{H}, \mathrm{d}^{3}{ }^{3} \mathrm{5}^{\prime}, 4^{\prime} 5.3 \mathrm{~Hz}, \mathrm{H} 5^{\prime}\right), 7.28\left(1 \mathrm{H}, \mathrm{dd},{ }^{3} J_{5^{\prime}, 4^{\prime}} 5.3,{ }^{5} J_{4,4^{\prime}} 0.5\right.$, $\left.\mathrm{H}^{\prime}\right), 5.31\left(2 \mathrm{H}, \mathrm{q},{ }^{3} \mathrm{~J} 7.0, \mathrm{CH}_{2}\right), 1.69\left(3 \mathrm{H}, \mathrm{t},{ }^{3} \mathrm{~J} 7.0, \mathrm{CH}_{3}\right) . \delta^{13} \mathrm{C}(100.613$ $\left.\mathrm{MHz} ; \mathrm{CDCl}_{3} ; \mathrm{Me}_{4} \mathrm{Si}\right) 270.9\left(\mathrm{C}_{\text {carb }}\right), 185.6\left(\left(\operatorname{Re}(\mathrm{CO})_{4}\right)_{c i s}\right), 184.4$ and184.2 $\left(\left(\operatorname{Re}(\mathrm{CO})_{4}\right)_{\text {trans to } \mathrm{C} 5 \text { and } \mathrm{Br}}\right), 156.9$ (C5), 140.1 (C4), 149.9 (C3), 140.8

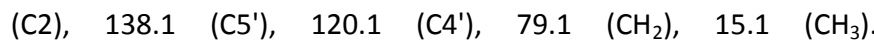
$\mathrm{m} / \mathrm{z}\left(\mathrm{C}_{13} \mathrm{H}_{8} \mathrm{O}_{5} \mathrm{~S}_{2} \mathrm{ReBr}, 573.86 \mathrm{~g} / \mathrm{mol}\right) 488.8269$ (34\%, [M-3CO-H]), 460.8296 (100\%, [M-4CO-H] $]^{-}$.

\section{Conclusions}

The preparation of new dirhenium FCCS 1, tetrarhenium biscarbene complexes $\mathbf{2}$, and subsequent efficient Re-Re bond cleavage of these FCCs by bromine resulting in the FCCs $\mathbf{3}$ and 4, are reported. Aminolysis of $\mathbf{1 a}$ with dimethylamine hydrochloride in a novel synthetic route resulted not only in the desired substitution of the alkoxycarbene substituent with a dimethylamino-group, but also in the cleavage of the Re-Re bond to give the monorhenium(I) tetracarbonyl chlorido amino-FCC 5a. Spectroscopic techniques (NMR, FT-IR, HRMS) and single crystal XRD were employed to confirm the structures of the compounds and to illustrate the electronic and structural effects of (i) the oxidative Re-Re bond cleavage with bromine on the metal-carbene ligand interaction, (ii) alkoxycarbene ligand substitution with aminocarbene ligand (3a vs $\mathbf{5 a}$ ), and (iii) the increased ring-delocalization pathway available in the FCCs (1) $\mathbf{b}-\mathbf{3 b})$ with the thieno[3,2-b]thienyl carbene substituent, compared to the thieno[2,3-b]thienylsubstituted FCCS (1a-3a). FT-IR and UV-Vis-NIR SEC measurements, and MO DFT calculations supported these findings, and confirmed the localization of the HOMOs on the rhenium carbonyl moieties; LUMOs delocalized across the carbene ligand; with larger band gaps for the $\operatorname{Re}(I)$ tetracarbonyl bromido monocarbene complexes than observed for the dirhenium(0) nonacarbonyl monocarbene complexes. As anticipated, electrochemical reduction yields radical anions with the negative charge delocalized across the carbene-TT ligand (more efficiently stabilized by the thieno[3,2-b]thienyl carbene ligands (series b) than by the thieno[2,3-b]thienyl carbene ligands (series a)), and in the case of the biscarbene FCCS 2, UV-Vis-NIR SEC also indicated the presence of through-bond intramolecular electronic communication between the terminal rhenium-carbene moieties.

\section{Conflict of interest}

There are no conflicts of interest to declare.

\section{Acknowledgements}

SR gratefully acknowledges Dr. Jannie Pretorius (UP) for the computational facility and financial support from the Flagship Programme of PISA (Photonics Initiative of South Africa). SL and NW acknowledge the NRF for financial assistance (NRF grants 87788 and 95772). DIB and ZL gratefully acknowledge the National Research Foundation, South Africa (NRF 105740 and 105529), and Sasol Technology R\&D Pty. Ltd., South Africa for financial support.

\section{References}

1 (a) S. Lotz, M. Landman, D. I. Bezuidenhout, A. J. Olivier, D. C. Liles and P. H. van Rooyen, J. Organomet. Chem., 2005, 690, 5929-5937; (b) M. M. Singh and R. J. Angelici, Inorg. Chim. Acta, 1985, 100, 57-63.

2 (a) R. Fraser, P. H. van Rooyen and M. Landman, J. Mol. Struct., 2016, 1105, 178-185; (b) D. I. Bezuidenhout, S. Lotz, M. Landman and D. C. Liles, Inorg. Chem., 2011, 50, 15211533; (c) S. Lotz, M. Landman, A. J. Olivier, D. I. Bezuidenhout, D. C. Liles and E. R. Palmer, Dalton Trans., 2011, 40, 9394-9403; (d) D. I. Bezuidenhout, D. C. Liles, P. H. Van Rooyen and S. Lotz, J. Organomet. Chem., 2007, 692, 774-783; (e) K. Osowska, K. Mierzwicki and S. Szafert, Organometallics, 2006, 25, 3544-3547; (f) U. Schubert, K. Ackermann and P. Rustemeyer, J. Organomet. Chem., 1982, 231, 323-334; (g) E. O. Fischer, T. L. Lindner, H. Fischer, G. Huttner, P. Friedrich and F. R. Kreissl, Z. Naturforsch., B: Anorg. Chem., Org. Chem., 1977, 32B, 648-652; (h) E. O. Fischer, E. Offhaus, J. Müller and D. Nöthe, Chem. Ber., 1972, 105, 3027-3035.

3 T. A. Waldbach, R. van Eldik, P. H. van Rooyen and S. Lotz, Organometallics, 1997, 16, 4056-4070.

4. For selected recent examples and reviews, see: $(a)$ F. Di Maria, M. Zangoli, I. E. Palama, E. Fabiano, A. Zanelli, M. Monari, A. Perinot, M. Caironi, V. Maiorano, A. Maggioro, M. Pugliese, E. Solatelli, G. Gigli, I. Viola and G. Barbarella, Adv. Funct. Mater., 2016, 26, 6970-6984; (b) X. Guo, Q. Liao, E. F. Manley, Z. Wu, Y. Wang, W. Wang, T. Yang, Y.-E. Shin, X. Cheng, Y. Liang, L. X. Chen, K.-J. Baeg, T. J. Marks and X. Guo, Chem. Mater., 2016, 28, 2449-2460; (c) X. Li, W. Jiang and Y.A. Son, Mol. Cryst. Liq. Cryst., 2014, 602, 1-8; (d) W. H. Wong, C.-Q. Ma, W. Pisula, C. Yan, X. Feng, D. J. Jones, K. Mullen, R. A. J. Janssen, P. Bauerle and A. B. Holmes, Chem. Mater., 2010, 22, 457-466; (e) I. F. Perepichka, D. F. Perepichka and H. Meng, in Handbook of Thiophene-Based Materials, ed. I. F. Perepichka and D. F. Perepichka, John Wiley \& Sons, Chichester UK, 2009, 695-756; (f) M. G. Hobbs and T. Baumgartner, Eur. J. Inorg. Chem., 2007, 3611-3628.

5 L. Brandsma, H. D. Verkruijsse, Preparative Polar Organometallic Chemistry I, Springer Verlag, Berlin, 1987, 125.

6 Z. Lamprecht, N. A. van Jaarsveld, D. I. Bezuidenhout, D. C. Liles and S. Lotz, Dalton Trans., 2015, 44, 19218-19231.

7 J. Fraser, W. R. Roper and F. G. A. Stone, J. Chem. Soc., Dalton Trans., 1974, 760-764.

8 M. L. Ziegler, H. Haas and R. K. Sheline, Chem. Ber., 1965, 98, 2454-2459.

9 D. M. Adams, Metal-Ligand and Related Vibrations, Edward Arnold Publishers Ltd, London, 1967, 100-101. 
10 For representative, recent examples of electrochemical studies on FCCs of metal carbonyls, see: (a) H. Kvapilová, I. Hoskovcová, J. Ludvík, S. Záliš, and J. Heyrovsky, Organometallics, 2014, 33, 4964-4972; (b) M. Landman, T. Levell, R. Pretorius, R. Fraser, B. E. Buitendach, M. M. Conradie, P. H. van Rooyen and J. Conradie, Electrochim. Acta, 2014, 130, 104-118; (c) B. van der Westhuizen, P. J. Swarts, L. M. van Jaarsveld, D. C. Liles, U. Siegert, J. C. Swarts, I. Fernández and D. I. Bezuidenhout, Inorg. Chem., 2013, 52, 6676-6684; (d) M. Landman, R. Liu, P. H. van Rooyen and J. Conradie, Electrochim. Acta, 2013, 114, 205-214; (e) B. van der Westhuizen, P. J. Swarts, I. Strydom, D. C. Liles, I. Fernández, J. C. Swarts and D. I. Bezuidenhout, Dalton Trans. 2013, 42, 5367-5378; (f) M. Landman, R. Pretorius, B. E. Buitendach, P. H. van Rooyen and J. Conradie, Organometallics, 2013, 32, 5491-5503; $(g)$ R. Metelková, T. Tobrman, H. Kvapilová, I. Hoskovcová and J. Ludvík, Electrochim. Acta, 2012, 82, 470-477; $(h)$ Tobrman, S. Záliš, R. Zvěrinová and J. Ludvík, Electrochim. Acta, 2010, 55 8341-8351.

11 G. M. Chu, A. Guerrero-Martínez, I. Fernández and M. A. Sierra, Chem. Eur. J., 2014, 20, 1367-1375.

12 D. K. Orsa, G. K. Haynes, S. K. Pramanik, M. O. Iwunze, G. E. Greco, D. M. Ho, J. A. Krause, D. A. Hill, R. J. Williams and S. K. Mandal, Inorg. Chem. Commun., 2008, 11, 1054-1056.

13 D. I. Bezuidenhout, B. van der Westhuizen, P. J. Swarts, T. Chatturgoon, O. Q. Munro, I. Fernández and J. C. Swarts, Chem. Eur. J., 2014, 20, 4974-4985.

14 (a) D. Aucamp, T. Witteler, F. Dielmann, S. Siangwata, D. C. Liles, G. S. Smith and D. I. Bezuidenhout, Eur. J. Inorg. Chem. 2017, 1227-1236; (b) B. van der Westhuizen, J. M. Speck, M. Korb, D. I. Bezuidenhout and H. Lang, J. Organomet. Chem. 2014, 772-773, 18-26; (c) D. I. Bezuidenhout, I. Fernández, B. van der Westhuizen, P. J. Swarts and J. C. Swarts, Organometallics, 2013, 32, 7334-7344; (d) B. van der Westhuizen, J. M. Speck, M. Korb, J. Friedrich, D. I. Bezuidenhout and H. Lang, Inorg. Chem., 2013, 52, 1425314264.

15 H. Meerwein, Org. Synth., 1966, 46, 113-115.

16 APEX3 (including SAINT and SADABS); BrukerAXS Inc., Madison, WI, 2016

17 G. M. Sheldrick, Acta Crystallogr., Sect. A: Fundam. Crystallogr., 2015, 71, 3-8.

18 G. M. Sheldrick, Acta Crystallogr., Sect. C: Cryst. Struct. Commun., 2015, 71, 3-8.

19 (a) R. J. LeSuer, C. Buttolph and W. E. Geiger, Anal. Chem. 2004, 76, 6395-6401; (b) F. Barrière, N. Camire, W. E. Geiger, U. T. Mueller-Westerhoff and R. Sanders, J. Am. Chem. Soc. 2002, 124, 7262-7263; (c) F. Barrière and W. E. Geiger, J. Am. Chem. Soc., 2006, 128, 3980-3989.

20 Gaussian 09, Revision B.01, M. J. Frisch, G. W. Trucks, H. B. Schlegel, G. E. Scuseria, M. A. Robb, J. R. Cheeseman, G. Scalmani, V. Barone, B. Mennucci, G. A. Petersson, H. Nakatsuji, M. Caricato, X. Li, H. P. Hratchian, A. F. Izmaylov, J. Bloino, G. Zheng, J. L. Sonnenberg, M. Hada, M. Ehara, K. Toyota, R. Fukuda, J. Hasegawa, M. Ishida, T. Nakajima, Y. Honda, O. Kitao, H. Nakai, T. Vreven, J. A. Montgomery, Jr., J. E. Peralta, F. Ogliaro, M. Bearpark, J. J. Heyd, E. Brothers, K. N. Kudin, V. N. Staroverov, T. Keith, R. Kobayashi, J. Normand, K. Raghavachari, A. Rendell, J. C. Burant, S. S. Iyengar, J. Tomasi, M. Cossi, N. Rega, J. M. Millam, M. Klene, J. E. Knox, J. B. Cross, V. Bakken, C. Adamo, J. Jaramillo, R. Gomperts, R. E. Stratmann, O. Yazyev, A. J. Austin, R. Cammi, C. Pomelli, J. W. Ochterski, R. L. Martin, K. Morokuma, V. G. Zakrzewski, G. A. Voth, P. Salvador, J. J. Dannenberg, S. Dapprich, A. D. Daniels, O. Farkas, J. B. Foresman, J. V. Ortiz, J. Cioslowski, and D. J. Fox, Gaussian, Inc., Wallingford CT, 2010.
21 GaussView, Version 5.0.9, R. D. Dennington II, T. A. Keith, and J. M. Millam, Semichem Inc., Shawnee Mission, KS, 2008.

22 N. M. O'Boyle, A. L. Tenderholt and K. M. Langner. J. Comp. Chem., 2008, 29, 839-845.

$23 \mathrm{http}: / /$ www.chemissian.com 